\title{
PUBLIC INFORMATION IS AN INCENTIVE FOR POLITICIANS: EXPERIMENTAL EVIDENCE FROM DELHI ELECTIONS
}

\author{
Abhijit Banerjee \\ Nils T. Enevoldsen \\ Rohini Pande \\ Michael Walton \\ Working Paper 26925 \\ http://www.nber.org/papers/w26925
NATIONAL BUREAU OF ECONOMIC RESEARCH
1050 Massachusetts Avenue
Cambridge, MA 02138
April 2020

For fieldwork and research assistance we thank Aditya Balasubramanian, Gaurav Chiplunkar, Sarika Gupta, Sandra Levy, Patrick Mayne, Cory Smith, Yashas Vaidya, Jeff Weaver, and Ariel Zucker. We thank Dominic Leggett and seminar participants for comments, and usaid div (AIDOAA-G-12-00006), National Science Foundation (1063693), 3ie (OW2.099) and International Growth Center for financial support. aea rct Registry is AEARCTR-0004975. The views expressed herein are those of the authors and do not necessarily reflect the views of the National Bureau of Economic Research.

NBER working papers are circulated for discussion and comment purposes. They have not been peer-reviewed or been subject to the review by the NBER Board of Directors that accompanies official NBER publications.

(C) 2020 by Abhijit Banerjee, Nils T. Enevoldsen, Rohini Pande, and Michael Walton. All rights reserved. Short sections of text, not to exceed two paragraphs, may be quoted without explicit permission provided that full credit, including $\odot$ notice, is given to the source. 
Public Information is an Incentive for Politicians: Experimental Evidence from Delhi Elections Abhijit Banerjee, Nils T. Enevoldsen, Rohini Pande, and Michael Walton

NBER Working Paper No. 26925

April 2020

JEL No. H4,O1,O12

\begin{abstract}
$\underline{\text { ABSTRACT }}$
In 2010, we informed a random set of Delhi councilors, some ineligible for re-election in their current ward, that a newspaper would report on their performance shortly prior to the 2012 city elections. Using slum dwellers' spending preferences, we created a councilor-specific index of pro-poor spending. Treated councilors increased pro-poor spending in high-slum wards. Crosscutting experiments suggest that the public nature of report cards, not access to information on public services per se, incentivized councilors. Data on party ticket allocation and electoral outcomes shows that, in low-information situations, credible public disclosures of politician achievements matters to both parties and voters.
\end{abstract}

Abhijit Banerjee

Department of Economics, E52-540

MIT

50 Memorial Drive

Cambridge, MA 02142

and NBER

banerjee@mit.edu

Nils T. Enevoldsen

nils@wlonk.com
Rohini Pande

Yale University

Department of Economics

27 Hillhouse Avenue

New Haven, CT 06520

and CEPR

and also NBER

rohini.pande@yale.edu

Michael Walton

John F. Kennedy School of Government

Mailbox 57

79 JFK Street

Cambridge, MA 02138

michael_walton@harvard.edu

A randomized controlled trials registry entry is available at AEARCTR-0004975 


\title{
Public Information is an Incentive for Politicians: Experimental Evidence from Delhi Elections
}

\author{
Abhijit Banerjee, Nils Enevoldsen, Rohini Pande and Michael Walton*
}

March 24, 2020

\begin{abstract}
In 2010, we informed a random set of Delhi councilors, some ineligible for re-election in their current ward, that a newspaper would report on their performance shortly prior to the 2012 city elections. Using slum dwellers' spending preferences, we created a councilor-specific index of pro-poor spending. Treated councilors increased pro-poor spending in high-slum wards. Cross-cutting experiments suggest that the public nature of report cards, not access to information on public services per se, incentivized councilors. Data on party ticket allocation and electoral outcomes shows that, in lowinformation situations, credible public disclosures of politician achievements matters to both parties and voters.
\end{abstract}

\section{Introduction}

Can government transparency increase politician accountability and make democracy work better for citizens? In this paper, we consider a specific aspect of this wider question. Can independent public validation of politician achievements, identified using freedom of information data, make politicians more responsive to the development preferences of their

*Authors are affiliated with MIT (Banerjee), Yale (Pande), Harvard (Walton), and unaffiliated (Enevoldsen), and are listed in alphabetical order. Emails: banerjee@mit.edu, nils@wlonk.com, rohini.pande@yale.edu, Michael_Walton@hks.harvard.edu. For fieldwork and research assistance we thank Aditya Balasubramanian, Gaurav Chiplunkar, Sarika Gupta, Sandra Levy, Patrick Mayne, Cory Smith, Yashas Vaidya, Jeff Weaver, and Ariel Zucker. We thank Dominic Leggett and seminar participants for comments, and USAID DIV (AID-OAA-G-12-00006), National Science Foundation (1063693), 3ie (OW2.099) and International Growth Center for financial support. AEA RCT Registry is AEARCTR-0004975. 
electorates? And does the behavior of political parties and the electorate validate politician responsiveness?

We experimentally test the effect of a credible promise of revealing performance information to voters in the context of Delhi's city government (Municipal Corporation) elections. We find that politicians' responsiveness to voter preferences increased. It also altered the pool of politicians: parties weeded out some of those with the weakest records. Consequently, voters' electoral choices became more responsive to politician performance.

Delhi is one of the world's most populous cities. It is divided into wards with a single councilor elected per ward for a five-year term. A gender quota that rotates across wards in each election cycle renders a fraction of incumbent male councilors ineligible to re-run from their current wards (henceforth "ineligible councilors"). (A cross-cutting caste quota is mostly nonrotating.) A ward's gender reservation status is only announced a few months before the election. A party can allocate an ineligible councilor a party ticket (i.e. the right to be the party candidate) for a unreserved ward. However, it can be difficult for the party to convey credible information about candidate quality in a new ward.

A councilor enjoys multiple policy levers. She receives an annual fund to spend on local development, typically the improvement of local infrastructure. She sits on committees which manage distribution of publicly provided private goods and public goods. More broadly, she is expected to be responsive to constituent demands.

Our primary field experiment - the newspaper report card experiment - occurred at scale covering 240 of Delhi's 272 wards. In 2010, two years prior to city elections, a random sample of incumbent councilors were informed that, using performance data obtained under India's Freedom of Information Act, a leading newspaper would report on their performance a month before the next election. For a random subset of treated councilors, the newspaper also immediately published midterm report cards, identical in structure to the final report cards. The additional midterm report card treatment may have enhanced the credibility of our primary treatment. However, it may have also had a councilor information effect, increasing the salience of performance indicators (and current performance). (It may also change citizen behavior and lead them, for instance, to hold a councilor accountable.)

Within the sub-set of high-slum wards, we therefore implemented a cross-cutting experiment to directly test for a councilor information (or salience) effect absent public disclosure. Treated councilors received a State of Sanitation Information (SSI) based on audit in three slums in their ward. This included geolocated information on quality of public toilets and garbage removal. Two audit reports were provided - eight and two months prior to the 
election. The information was never made public.

To evaluate whether disclosures - either anticipated public or real-time private ones better align councilor spending with citizen preferences requires knowledge of citizen spending preferences (which likely vary by neighborhood characteristics). Here, we make use of a slum survey that we conducted prior to launching the experiments. Using data from residents in over 100 high-slum wards on their public spending preferences, we construct preference weights for spending categories. Our focus on slum dwellers had multiple motivations. First, slum infrastructure investments - for instance, building and repairing drains - are relatively inexpensive high-return investments for councilors, precisely because slum infrastructure is so bad. Second, unlike other administrative funds that can only be used in legal settlements, councilor funds can be invested in slums. Finally, our sampling choice reflected our interest in whether anticipated performance disclosures can make elected governments more accountable to poor citizens.

Figure 1 shows a large divergence between slum dwellers' infrastructure priorities and councilors' spending choices. Nearly $70 \%$ of our respondents describe sanitation (sewage and drainage) as a concern, but only $16 \%$ of councilor funds are spent on it, against $54 \%$ on roads, despite the fact that only $2 \%$ of our respondents complain about roads. Why do we see this disparity? We conjecture that electoral returns to local sanitation improvements are low as they are less visible. Figure 2 provides corroborative evidence: Over a quarter of respondents believe that their councilor spends the least on sanitation. In comparison, only $5 \%$ believe their councilor spends the least on parks and greenery, and $2 \%$ believe she spends the least on schools. In reality, councilors spend $16 \%$ of their budget on sanitation, but only $7 \%$ on parks and greenery and $3 \%$ on schools.

Newspaper report cards thus provide an opportunity to inform (and advertise) councilor performance on sanitation. Therefore, at least for high-slum wards, anticipated public disclosures should incentivize councilors to move spending towards less visible but highly valued investments (i.e. in a pro-poor direction). ${ }^{1}$

Anticipated newspaper report card disclosures led spending allocations of councilors of high-slum wards to be 0.62 standard deviations more pro-poor. We also observe a 0.37 standard deviation increase in their assembly and committee attendance. The estimated effects are similar across treatment arms: councilors who only anticipated disclosure in 2012 and those who additionally received a midterm report card in 2010. This argues against

\footnotetext{
${ }^{1}$ We define high-slum wards as wards where the fraction of slum area is above the median value computed across all wards
} 
Figure 1: Councilor spending and constituent preferences

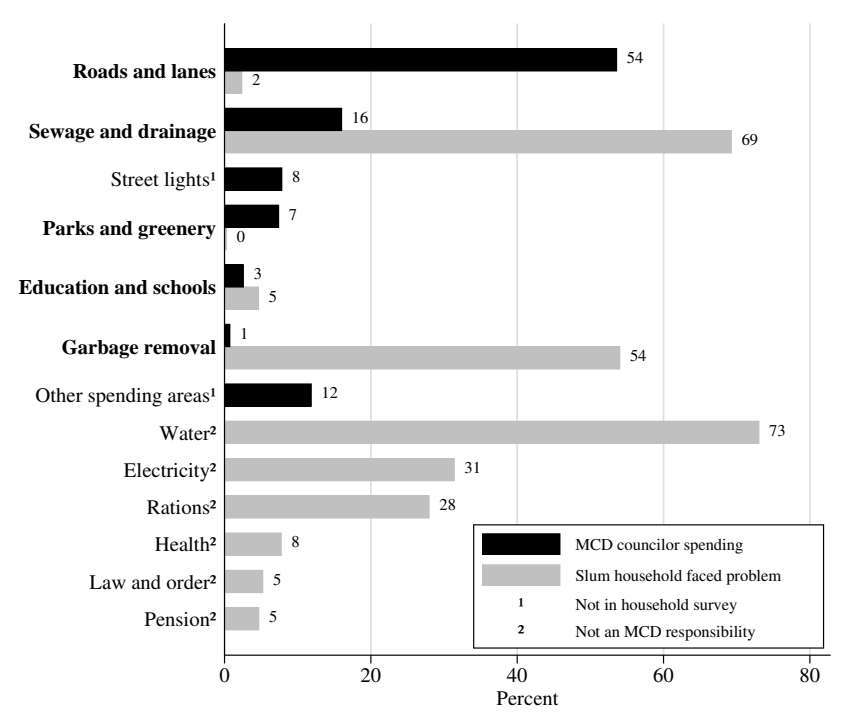

"MCD councilor spending" is the ward-mean of annual fraction of councilor spending (2007-2012). "Slum household faced problem" is the ward-mean of slum households who specify each category in response to the question, "In which of the following areas have you personally faced problems in the last year?" Household responses are weighted within wards. Bold face indicates areas that are included in preference-weighted spending measures.

any additional value from early information associated with the midterm report card.

In contrast, actionable information via the private SSI treatment did not improve sanitation. This is consistent with our conjecture that the public nature of disclosure matters, especially for less visible investments. For example, many citizens see public health gains from sanitation improvements during monsoons, because drains don't flood. However, they recognize these gains only if the monsoon floods are sufficiently severe. Additionally, since wards have about 50,000 residents each, some investments that are locally visible will lack visibility to voters farther away. This limits the direct spread of information about politician investments from affected voters to a broader voting public. Newspaper report cards can amplify information about such investments. First, because many voters routinely obtain information via newspapers. And second, because parties use them to advertise candidates to voters. The advertising effect can cause parties to favor allocating party tickets to candidates with a good report card, especially where they are less known, because they are easier to advertise. 
Figure 2: Constituent beliefs and preferences about councilor spending

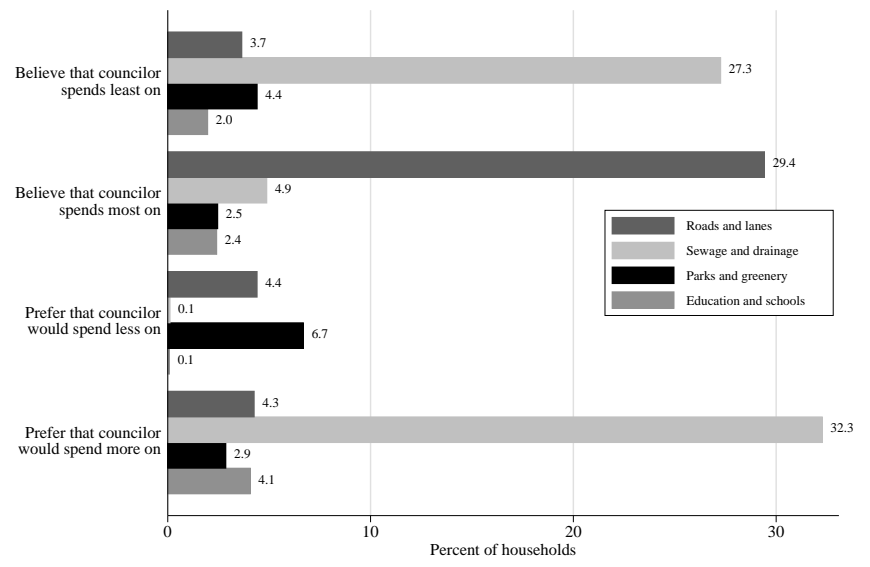

Each bar represents ward-mean of slum households who specify each category in response to, "What type of project do you think your councilor spends most (least) on?" and, "What type of project do you think you councilor spends too much (little) money on?" Household responses are weighted within wards.

Respondents were prompted with project categories. (The figure presents categories included in preference-weighted spending measures; other prompts were "Water", "Health", and "Community centres." Beliefs and preferences about spending on garbage collection were not elicited.)

To evaluate this hypothesis for why public disclosures influenced councilor behavior, we turn to party and voter behavior in the 2012 elections. Four months prior to the April 2012 elections, the government unexpectedly announced an increase in the number of wards reserved for women from $33 \%$ to $50 \%$. They also decided to randomize the reservation status of wards. One third of incumbents in our sample were rendered ineligible to re-run for election from their current ward. ${ }^{2}$ For ineligible councilors, the party faces a much sharper decision: Should it allocate a ticket to an ineligible councilor for a different (unreserved) ward where he will be less well-known (and perhaps have less opportunity to engage in clientelistic politics)?

The newspaper report card treatment influenced party ticket allocation. Treated incumbents were 12 percentage points more likely to run for re-election, with the effect concentrated among ineligible councilors. Within this group, ineligible treated incumbents with a standard deviation more pro-poor spending than their counterparts were 13 percentage points more likely to get a party ticket for a different ward. We also find suggestive evi-

\footnotetext{
${ }^{2}$ While all councilors would have anticipated some likelihood of being ineligible, the increase in quotas and choice of reserved wards was a surprise. Consistent with this, we show that report card impacts on spending are unaffected by a councilor's subsequent eligibility status.
} 
dence that the effects were concentrated among ineligible incumbents in high-slum wards, and that some good performers were moved to other high-slum wards.

Turning to the group of eligible councilors, roughly half of them received party tickets to run from their current ward while only $2 \%$ received a ticket for a different ward. Report cards don't benefit better performing councilors when it comes to ticket allocation. Thus, it appears that the party perceives that electoral benefits from a good newspaper report card are valuable when a councilor needs to run in a different ward, where he is less known.

Ticket allocation treatment effects among ineligible councilors translate into electoral gains. (One has to run to gain votes, but running does not guarantee winning.) Treated ineligible councilors with a pro-poor spending record that is one standard deviation above counterparts are 23 percentage points more likely to win. In contrast, and consistent with the absence of ticket allocation treatment effects for this group, we see no treatment effects on vote share within the pool of eligible councilors.

Good newspaper report cards on ineligible councilors provide the party with reputational benefits. The incumbent party's vote share rises in a report-card treatment ward where the incumbent performed well but was rendered ineligible. This ward-level treatment effect is absent when a high-performing incumbent candidate remained eligible. The latter may reflect the fact that across eligible councilors there is a second effect at work: voter displeasure with the party when eligible good performers do not getting a party ticket.

Our final result comes from randomization of the mix of four councilors whose report cards were published in the same newspaper issue. Conditional on absolute performance, an ineligible councilor who performs better relative to the other councilors featured in the same newspaper edition is both more likely to get a party ticket and to receive a higher vote share. This is further evidence that is supportive of a party advertising view - it is easier to pitch a candidate when she is the best on the page - but also of an information view - voters benchmark their candidate relative to the others on the page.

To summarize, anticipated public disclosures led councilors in high-slum wards to move their spending in a pro-poor direction. The party and electoral impacts of good performance are concentrated among the group of ineligible councilors. For this group, we posit that the advertising effect is particularly important since, if they received a ticket, it would be in a ward where they are less known. Conversely, voters recognize that the party could not have fielded the candidate in the current ward. The party, therefore, benefits from a high-performing ineligible councilor's reputation in the current ward as well. 


\section{Contribution to the Literature}

Observational studies of the impact of media, typically, report a positive link between media presence and quality of policies but have limited ability to disentangle selection and incentive effects (Besley and Burgess 2002; Strömberg 2004; Snyder Jr and Strömberg 2010). We provide the first at-scale experimental study, conducted in conjunction with a daily newspaper, that isolates how media can engender incentive effects for politicians.

Recently, experimental studies on information disclosures have expanded. A first strand of this literature reports on selection by voters in response to pre-election information disclosures. These disclosures, especially when publicized by media, are associated with corrupt incumbents faring worse in subsequent elections (Ferraz and Finan 2008), and likewise for low-performing incumbents (Banerjee et al. 2011; Kendall et al. 2015). Chong et al. (2014) highlight that a negative turnout effect can counter this selection effect. The impacts are also muted or absent when information is delivered through non-media sources such as pamphlets (Dunning et al. 2019). Finally, the impacts of soft information - for instance, candidate debates - are sensitive to what the voters infer from it (Bidwell et al. 2019; Wantchekon 2003; Fujiwara and Wantchekon 2013).

A second strand examines politician reactions to information disclosure. In the Philippines, areas where beliefs about incumbent mayoral candidates were most adversely affected by an information campaign saw more vote-buying (Cruz et al. 2016). Relatedly, candidates in Sierra Leone increased campaign expenditures in areas where candidate debates were screened (Bidwell et al. 2019).

The final strand, and the one closest to our paper, evaluates longer-term effects of anticipated disclosures on incumbent behavior. Bobonis et al. (2016) exploits the fixed schedule of municipality audits in Puerto Rico. Mayors expecting pre-election information disclosures are honest prior to, but not after, election. In contrast, Avis et al. (2018) observe durable positive impacts of expected audits in Brazil on corruption among mayors.

Corruption by politicians is sensitive to the electoral incentives they face, at least in the short run. However, corruption and other governance failures differ in important ways. First, while accusations and counter-accusations of corruption are common in electoral politics, the key is to be credible, and to be credible the auditing authority must be independent and the evidence must be solid. For this reason such exposures are typically rare, unless a lot of resources are put behind the anti-corruption authority. ${ }^{3}$ Put differently, credible

\footnotetext{
${ }^{3}$ Avis et al. (2018) emphasize the prestige and credibility of a Brazilian auditor's job.
} 
corruption accusations are expensive to bring about and big news when they happen.

Second, behind every corruption investigation there is the possibility of prosecution. Avis et al. (2018) argue that the fear of prosecution can explain the entire effect on corruption that they find. While Bobonis et al. (2016) does not disentangle judicial and electoral incentives, if pre-election report cards attract more attention than those published after, then the impact could partially come from similar prosecution concerns.

By focusing on councilor performance, captured by information about spending of discretionary funds, we consider a substantively different, and increasingly important, aspect of performance. While India and Kenya are among the best-known examples of countries that provide elected officials with discretionary constituency funds, such funding is on the rise (International Budget Partnership 2010). The concomitant rise of freedom of information acts in lower-income countries makes performance disclosures based on routinely collected government data increasingly feasible (Mendel 2014). It is possible that councilor performance in areas valued by voters is less visible and/or the set of voters that have direct knowledge is relatively small. Both these reasons would suggest that credible and broad-based transmission of information about councilor fund use can matter. ${ }^{4}$

In summary, we evaluate the impact of relatively easy to obtain information, whereas corruption audit studies consider costlier and more sensitive information. The fact that one works tells us relatively little about whether the other will work.

A closely related paper is Grossman and Michelitch (2018), a field experiment in Uganda where a CSO produced annual performance score cards for politicians. They also find that public disclosure to citizens was critical; however, unlike our study, they rely on CSO intermediation. $^{5}$

We trace the full causal chain from the announcement of future report cards, through politician behavior, all the way to the electoral fortunes of targeted politicians and their parties. In doing so, we study an important but understudied question: How do information disclosures influence the competition for party nomination? In related work, Besley et al. (2017) found that gender quotas increased intra-party competition among Swedish men and thereby leadership quality. ${ }^{6}$ As in our paper, they find that binding gender quotas engender

\footnotetext{
${ }^{4}$ The impact of corruption information on electoral outcomes as reported in Ferraz and Finan (2008) are substantially larger than those of performance information, as reported in Banerjee et al. (2011).

${ }^{5}$ The CsO created aggregate politician assessment while in our case, the NGo reported spending data, in part because, as we will see, low and high income voters have different preferences. In addition, the CSO in Uganda disseminated report cards through public meetings (preceded by community mobilization). Our experiment, by contrast, relied on the newspaper publishing report cards.

${ }^{6}$ Our work is also related to papers on gender quotas in Indian politics - for instance, Beaman et al.
} 
greater selection among men. We provide causal evidence of such a selection mechanism, since the party responds differently to ineligible candidates with similar spending records but who differ in whether a report card was produced.

\section{Setting and Experimental Design}

\subsection{Electoral and administrative structure of Delhi}

\section{A. Elections}

With a population of over 18 million, Delhi ranks among the world's largest cities. Between a quarter and a half of Delhi's population lives in slums (Delhi Human Development Report 2006). ${ }^{7}$ Delhi has a two-tier elected governance structure: a state legislature and a city government. We focus on the city government, termed the Municipal Corporation of Delhi (MCD). Plurality rule MCD elections occur every five years; each of the 272 city wards elects a councilor. The party/coalition with the majority of councilors controls the corporation.

Our experiments spanned the two years in the run-up to the April 2012 election. Of the 272 incumbents elected in the previous election in 2007, India's two main national parties, BJP and INC, had the largest share of councilors at $65 \%$ and $25 \%$ respectively. Party leaders nominate candidates for each ward; there are no primaries.

These elections are subject to political affirmative action (quotas), for two groups: scheduled castes (SC) and women. Only members of an identified group can stand for election in a ward reserved for that group. Four months prior to 2012 elections, the Delhi government announced that gender quotas would increase from $33 \%$ to $50 \%$ and be stratified by SC reservation status. Specifically, within each of the categories of SC reserved wards and other wards, half the wards would be reserved for women. ${ }^{8}$ Wards in each category were listed by (ascending) serial number with every odd seat reserved for a woman. Thus, wards reserved for women were chosen effectively at random. ${ }^{9}$

(2012) find that quotas increased political entry by women.

${ }^{7}$ The difference in estimates reflect differences in slum definition: for instance, whether they only include notified slums (which were legally notified or declared as slum areas under the Slum Areas (Improvement and Clearance) Act of 1956) or also include non-notified slums (typically illegal encroachment on land) (DUSIB 2010). Residential status does not affect voting rights.

${ }^{8} \mathrm{SC}$ ward reservation is based on their ward population share, with priority given to wards with higher $\mathrm{SC}$ population.

${ }^{9}$ One additional level of stratification was used: In 2011 Delhi was split into three separate municipal corporations, with all wards being assigned to one of the three. The SC reservation was implemented within 


\section{B. Councilor policy powers}

Very broadly, councilors have access to four policy levers. First, via legislative activism: Between 2007 and 2012, the MCD met, on average, 24 times per session. The average councilor attended 19 times per session.

Second, councilors are assigned to standing committees which are intended to meet regularly and be responsive to citizen complaints about various government services.

Third, councilors receive an annual discretionary fund for development works in their ward. The annual amount varies and averaged 200,000 USD per year during the 20072012 election cycle. ${ }^{10}$ Figure 1 shows the fraction spending in different categories for the pre-treatment period (2007-09). Alongside, we summarize areas of perceived problems, as reported in a household survey of slum dwellers and by neighborhood associations (these surveys are described in the data section). Prima facie there is evidence of a mismatch between reported needs and spending - we discuss this further in Section 3.3.

Fourth, councilors provide and maintain local public goods including public toilets, garbage removal, and drain cleaning. Toilets and garbage removal are managed on a contractual basis by private or non-government organizations. ${ }^{11}$ Councilors help choose the contractor, and can pressure or sanction them for non-delivery, in addition to directly spending discretionary funds on fixing toilets or improving the garbage collection process.

\subsection{Experimental Design}

\section{A. Partners}

Our experiment on information disclosure was made possible by three partners. First, Satark Nagrik Sangathan (SNS), or Society for Citizens Vigilance Initiatives, which has a mandate to promote transparency and accountability in government functioning. It was involved with the passage of the 2005 Right to Information law (RTI), which allows citizens

each municipal corporation and then the reservation for women was implemented separately within each set of SC reserved and unreserved wards, as described.

${ }^{10}$ The amounts were Rs. $7.1 \mathrm{M}$ in $2007-08$, Rs. $20 \mathrm{M}$ in 2008-09, Rs. 5.0M in 2009-10, Rs. 5.0M in 2010-11, and Rs. $9.5 \mathrm{M}$ in $2011-12$.

${ }^{11}$ The typical toilet contract sets maximum user price, states necessary facilities and requires regular cleaning. 20-30 year contracts are awarded per facility, with a clause that should "unsatisfactory" conditions fail to be improved within 15 days after notice is given, the contract may be rescinded. Garbage contracts stipulate that operators provide bins for non-biodegradable and recyclable/biodegradable waste, and segregate and collect waste daily (IL \& FS Ecosmart Limited 2006). The typical garbage contract is nine years, awarded at the zonal level, and includes a performance evaluation mechanism. 
Figure 3: Example MCD councilor report cards in the Hindustan, 2012

\begin{tabular}{|c|c|c|c|c|c|c|c|c|}
\hline $\begin{array}{l}\text { आपके } \\
\text { पार्षद }\end{array}$ & \multicolumn{2}{|c|}{$\begin{array}{l}\text { प्रोमिला घई } \\
\text { पारी : माजापा } \\
\text { जनक पुरी पथिवन } \\
\text { वाई नंबर : } 117\end{array}$} & \multicolumn{2}{|c|}{$\begin{array}{l}\text { निर्मल जैन } \\
\text { पार्टी: आजणा } \\
\text { शाहदरा } \\
\text { वाई नंबर : } 237\end{array}$} & \multicolumn{2}{|c|}{$\begin{array}{l}\text { सत्य शना } \\
\text { पार्टी: आजाजपा } \\
\text { न्यु उस्नान पुर } \\
\text { वाईड नंबर : } 251\end{array}$} & \multicolumn{2}{|r|}{$\begin{array}{l}\text { नेर्देलीय } \\
\text { उरी } \\
\text { श : } 244\end{array}$} \\
\hline & \multicolumn{2}{|c|}{ 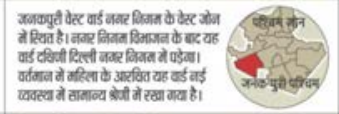 } & \multicolumn{2}{|c|}{ 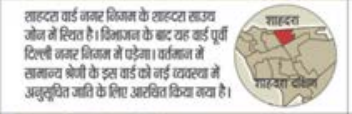 } & & & & \\
\hline & \multicolumn{2}{|c|}{ निमम की केठकों मे उपस्थिति स्थात पूछे } & \multirow{2}{*}{\multicolumn{2}{|c|}{$\begin{array}{l}\text { निगम की वेठकों मे उपस्थिति } \\
\begin{array}{ll}99 / 104 & \text { सवात पूछे } \\
02\end{array}\end{array}$}} & & \multirow{2}{*}{\multicolumn{2}{|c|}{ 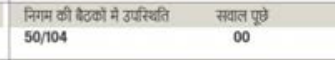 }} \\
\hline & $97 / 104$ & & & & & & & \\
\hline $\begin{array}{l}\text { समितियों में } \\
\text { प्रदर्शन } \\
\text { (आप्रैल 2007 से } \\
\text { मार्च 2011) }\end{array}$ & \multicolumn{2}{|c|}{ 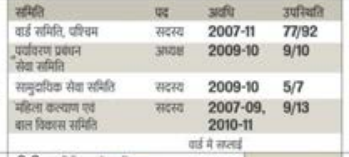 } & \multicolumn{2}{|c|}{ 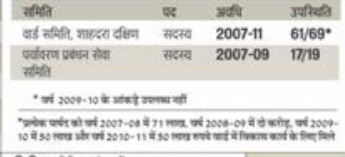 } & \multicolumn{2}{|c|}{ 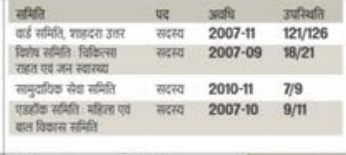 } & \multicolumn{2}{|c|}{ 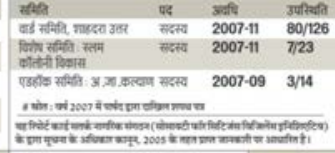 } \\
\hline $\begin{array}{l}\text { पार्षद निधि के } \\
\text { खर्च का ब्योरा } \\
\text { (फीसदी मे) }\end{array}$ & \multicolumn{2}{|c|}{ 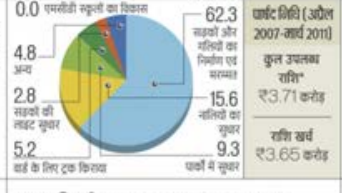 } & \multicolumn{2}{|c|}{ 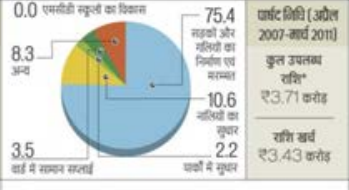 } & 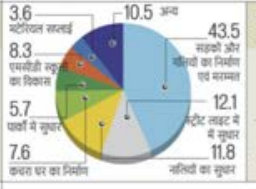 & 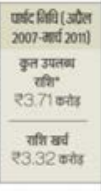 & \multicolumn{2}{|c|}{ 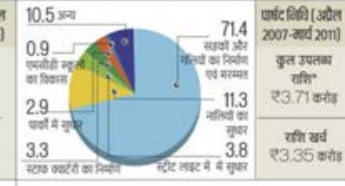 } \\
\hline & \multicolumn{2}{|c|}{ 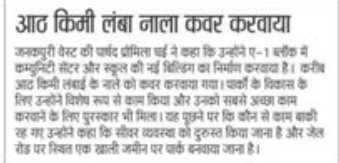 } & \multicolumn{2}{|c|}{ 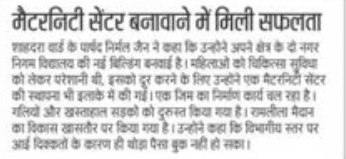 } & \multicolumn{2}{|c|}{ 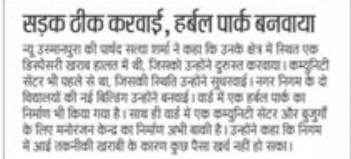 } & \multicolumn{2}{|c|}{ 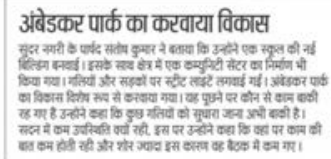 } \\
\hline
\end{tabular}

to obtain official information about the functioning of the government. SNS has a long history of creating and then, in partnership with media outlets, disseminating report cards on incumbent performance and qualifications of leading candidates for state and national legislatures. Banerjee et al. (2011) evaluated one such experiment during the 2010 Delhi state elections and found that it increased the vote share of better performing candidates.

Our second partner was a leading Hindi daily newspaper, Dainik Hindustan which, at the time of our experiment, was the second largest newspaper in Delhi in terms of market share. The newspaper published report cards on incumbents (prepared by SNS) in 2010 and 2012. Figure 3 is an example of one daily report in 2012: it includes report cards on four councilors. For each councilor, it includes herphoto, patterns of spending from her discretionary funds, which committees she served on, and her attendance at those committees. There is no overall assessment or grade provided; rather, the reader is invited to make her own mind up based on these relatively objective numbers.

Our third partner was the JPAL South Asia team that conducted toilet, garbage, and drain audits and disseminated the State of Sanitation Information privately to councilors. 


\section{B. Newspaper report card experiment}

Sample Our sample consists of 240 wards, with treatment assignment stratified on incumbent party and zone. ${ }^{12}$ We randomly assigned 72 to be control wards, 58 to only receive pre-election report cards (T1) and 110 to receive both midterm and pre-election report cards (T2). Figure 4 shows a map of wards in our sample.

Figure 4: Map of Delhi wards by treatment status

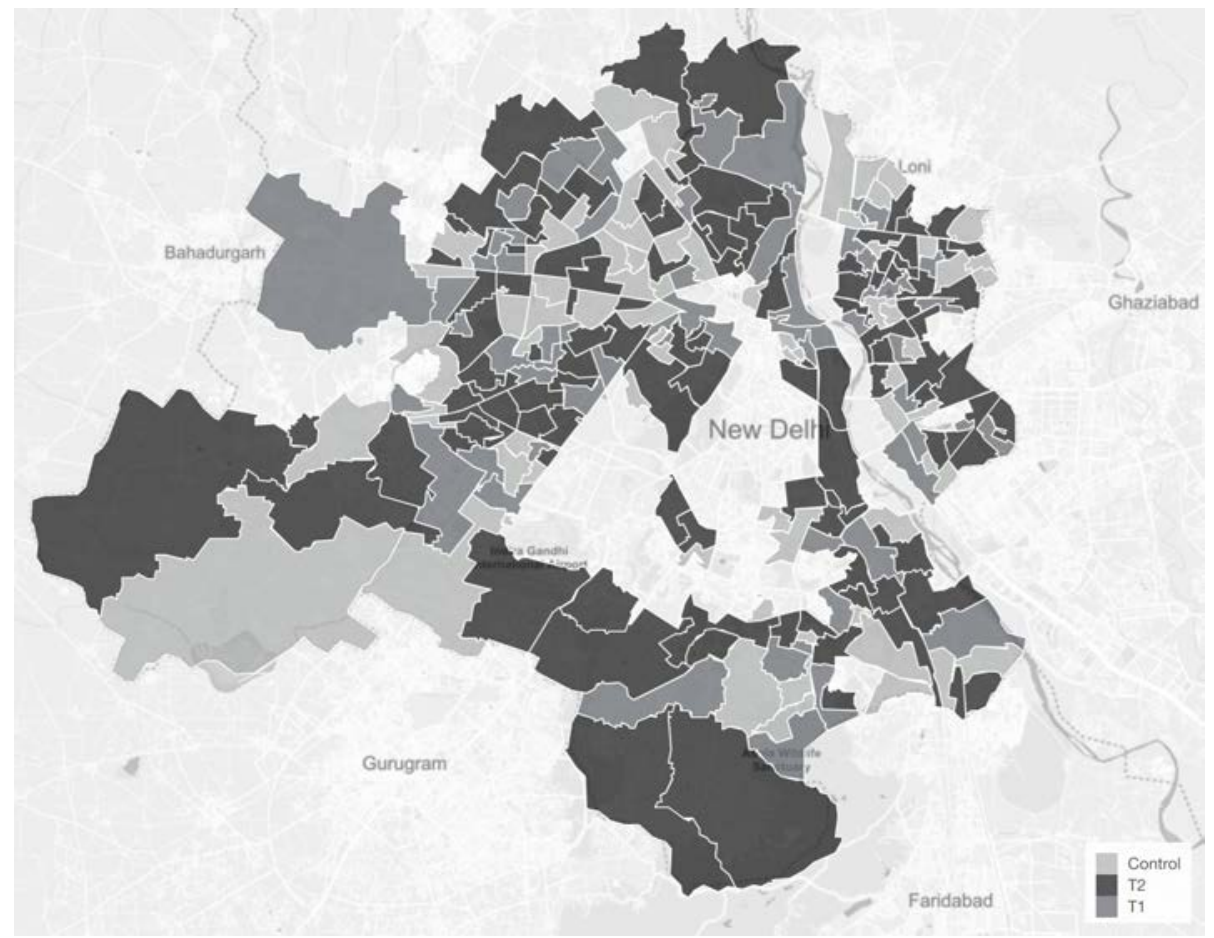

Informing politicians about report cards Treatment councilors received a letter in June 2010 from our partner organization SNS. Appended to the letter was a copy of the first set of report cards published by the newspaper on May 27, 2010. Common text in the letters across treatment arms was:

SNS uses the RTI Act to obtain objective information on the functioning of elected representatives and disseminates this information in the form of Report Cards. We collaborate with the media to disseminate these Report Cards.

\footnotetext{
${ }^{12}$ We excluded 32 of Delhi's 272 wards: 5 where SNs was doing community work, 10 where by-elections occurred less than two years ago, and two zones (17 wards) with few or no slums, including rural areas.
} 
Prior to the Delhi Assembly elections in 2008, SNs developed Report Cards to disseminate information about the functioning of all 70 MLAs in Delhi. Similarly, before to the 2009 Lok Sabha elections, they developed Report Cards on the performance of about 250 prominent Members of Parliament of the country. SNS ran joint campaigns with Hindustan, the Times of India, Outlook magazine etc to disseminate these report cards.

SNS prepared midterm report cards of MCD councilors to inform people of the development work being done by councilors for the welfare of ward residents. Due to limited resources, we have not been able to prepare report cards for all 272 councilors in Delhi. We have randomly selected 110 wards for which report cards are being prepared. The party-wise break up of the sample is the same as in the MCD. As you might be aware, these report cards are being published by the Hindi newspaper Hindustan (please find attached the report cards that appeared on May 27, 2010 in Hindustan)

The T1 letter then went on to state

Unfortunately, your ward is not in the list of 110 wards for which report cards are being prepared this time. However, in 2012, we will again be preparing report cards for these and more wards in Delhi. In 2012, we intend to include your ward.

The T2 letter instead stated

Your ward is one of the 110 wards for which the report card has been prepared. In 2012, we will again be preparing report cards for these 110 wards and for more wards in Delhi. We hope that dissemination of these report cards based on objective information will help people understand the development efforts being made by councilors for the welfare and betterment of their wards.

The councilors in control wards received a letter that they were not selected for report cards and would not be reported on until at least 2014 (two years after the election). All treatment councilors received a reminder letter in February 2011.

Report card format Our NGO partner SNS used the RTI Act to obtain data from the MCD on councilor spending, meeting attendance, and committee membership. 
For midterm report cards, over (roughly) a month starting on May 27th 2010, the newspaper featured three report cards daily. Each report card included the councilor's photo, spending patterns for discretionary funds, and committee attendance. The data reported on covered the period between April 2007 to March 2009, inclusive.

The 2012 report cards had the same format as those issued in 2010, but were published in groups of four. They covered the time period between April 2007 to March 2011. As data is released by fiscal year, we lacked spending data for the last year of the councilor's term. The report cards were published in March 2012, the month prior to the election. On a given day the newspaper featured four councilors. Because of publication constraints, we were unable to publish all 2012 report cards before the 2012 election. We prioritized publication of report cards for councilors eligible for reelection. Of 168 report cards for ITT councilors, 124 were published, comprising all report cards for eligible councilors and half of those for ineligible councilors.See Appendix 8.2 for details. Throughout, we report ITT estimates.

We use the publication of four report cards on a single newspaper page to evaluate yardstick competition, i.e. whether parties (and voters) valued a councilor's relative performance. Report card placement on a newspaper page occurred in two steps. First, report cards were categorized into comparable groups (by zone, eligibility, and "slumminess") and within each group the wards were grouped into pairs. Next, two pairs were randomly chosen to feature on the same page.

\section{Private State of Sanitation Information (SSI) experiment}

Can information on public good provision problems in a ward, absent public disclosure, suffice to influence councilor behavior? To evaluate this possibility, the ssi treatment provided councilors information on the state of toilets and garbage dumps in slums in their wards. Recall from Figure 1 that sanitation and garbage were the two categories (where councilors could act) which slum dwellers identified as the most problematic. The information was privately conveyed and not put in the public domain.

Sample Our audits covered the sample of 108 high-slum wards where we also undertook baseline surveys. We undertook a two-stage randomization. First, we randomized state election jurisdictions into treatment and control and then randomized wards within treatment jurisdictions into treatment and control. In each ward we audited, on average, three 
slums, giving us a sample of 310 slums across 108 wards. See Data Appendix 8.3 for details.

Information reporting The reports were based on public toilet and garbage dump (dhalao) audits in each slum. Three SSI audit rounds were conducted, with reports based on the first two mailed to councilors (and legislators) in treatment groups. The first round of SSI was distributed in August 2011, about eight months before the elections for councilors, and the second round was sent in February 2012, only a couple of months prior to the elections. The first summarized the baseline SSI audits conducted between April and June 2011 (Round 1), and the second compiled SSI audits conducted between November 2011 and January 2012 (Round 2). The final round of SSI audits occurred immediately after the MCD elections, from April through June 2012 (Round 3). Cover letters sent to the legislators along with the audit result, explained the context behind the SSI audits. A cover letter for the second round ssi audit read in part:

As part of a study on urban poor in Delhi, we conducted a survey in 2010, which was done with [number of] families of your ward [ward identifier] in slum settlements and in low-income areas. Of these families, [percentage] reported that public toilets and sanitation are a major problem for their community, and [percentage] reported that garbage was a major problem for their community.

You may recall, in September 2011, we sent you a report card in which we highlighted the condition of the garbage collection points and public toilet facilities in your ward's slum settlements and in low-income areas. We have recently completed the second round of audits of garbage and toilet facilities in these areas, and we are again sharing this information with you. We hope this can be useful in your ward-related work. Our auditors have tried to cover all garbage points and public toilets in the slum settlements and in low-income areas that were audited.

Information gathered by our auditors in your ward is enclosed with this letter. In the first part of the report card there is a summary of the status of audited garbage and toilet facilities, and in the latter part, their details. We are also enclosing a map of all these facilities where your attention is needed. Each facility has been assigned a code which is placed on its location on the map, so that you can easily identify it. 
Figure 5: Experiment timeline

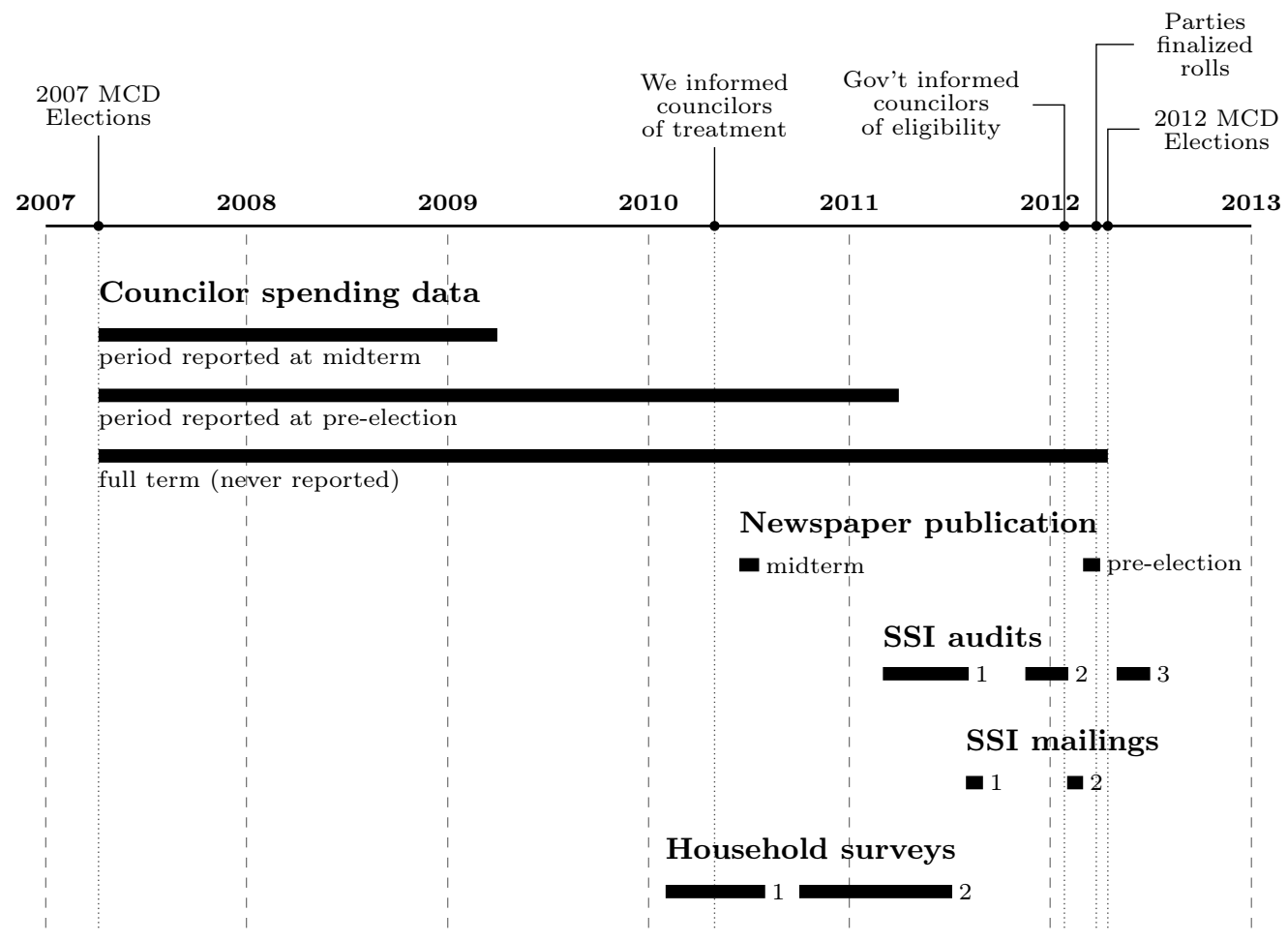

Information on the state of drains was collected, but not shared with politicians, during the second and third rounds of SSI audits. Spillover effects on this service could have been positive, if, for example, the audits made them more aware of the problems in those slums, or negative if there was a diversion of effort away from drains.

Figure 5 summarizes the experiment and data collection timeline.

\subsection{Data and Descriptive Statistics}

Our experiments, and subsequent analysis, draw upon multiple sources of data.

\section{A. Citizen preferences and slum incidence}

We use aerial data on slum incidence to define a high-slum ward dummy that equals one if the fraction of slum area in that ward exceeds the median value across all wards (about 1\%). High-slum wards have a mean of $7 \%$ slum area across 3.1 slums. Low-slum wards have a mean of $0.1 \%$ slum area across 0.7 slums. Data Appendix 8.1 describes our ward selection, 
and our sample frame of slums. In April-May 2010 (prior to launching our experiment), we surveyed 5,481 slum households in 107 wards. ${ }^{13}$ Survey respondents were typically long-term migrants: our average respondent had lived in Delhi for seventeen years.

Figure 1 shows low alignment between (category-wise) councilor spending and problem areas identified by slum dwellers. Councilors spend a majority of their funds (57\%) on roads, an area with significant corruption in contracting (Lehne et al. 2018). Roads are also a visible form of infrastructure investment. Arguably, both factors make road investments valuable to councilors. In contrast, slum dwellers report clean water, sewage management, and garbage collection as the most problematic issues. Water in Delhi is privately provided and is beyond the remit of the councilors; however drains and toilets are not. Despite this, spending on drains and toilets at $17 \%$ constitutes a low proportion of councilor funds (relative to roads). The next two highest expense categories for councilors also do not meet slum dwellers' interests: provision and repair of lights (8\%) and improvement of parks and provision of gates (7\%). In particular, slum dwellers express no interest in spending on parks and greenery, which are typically located in non-slum neighborhoods.

Figure 2 reports slum dweller beliefs and preferences over councilor spending. Over a quarter believe that councilors spend the most on roads and the least on sanitation. Roughly a third would like the councilor to spend more on sanitation.

A comparison of actual spending with slum dweller beliefs (Figure 1 and Figure 2) suggests that more visible infrastructure spending items (roads and parks and greenery) are more salient to slum dwellers. For instance, respondents strongly believe that councilors spend less on sewage and drains than on parks and greenery. In reality, councilors spend twice as much on sanitation as on parks and greenery.

In 94 of these wards we surveyed 250 office-holders of Resident Welfare Associations (RWAs) which represent households with legal status in the ward (and which are, on average, richer than slum dwellers). ${ }^{14}$ Slum dwellers and RWA residents have different preferences: RWA residents are ten times more likely to name roads as an important problem, put less (but still substantial) emphasis on sewage, drainage, and garbage disposal and are keen on parks and street lights, two items that the slum dwellers never name. ${ }^{15}$

\footnotetext{
${ }^{13}$ This was intended to be identical to the audit sample. Due to slum mis-identification and other surveying errors, the survey sample does not include four audit wards, but includes three other wards.

${ }^{14}$ RWAs are neighborhood associations that can formally interact with state agencies (Government of National Capital Territory of Delhi 2014). Our RWA sample was drawn from the Delhi government list, which we matched to wards based on the RwA's stated address. Not all survey wards had registered RWAs.

${ }^{15}$ Detailed results are available from authors on request.
} 


\section{B. Councilor performance data}

SNS collated councilor performance data for all wards; only treatment ward data was subsequently released as newspaper report cards. The report card included category-wise spending of discretionary funds by the councilor (see Figure 1). ${ }^{16}$

We combine these data with survey data on slum dwellers' preferences for infrastructure to construct a pro-poor spending index as follows. We use a five category spending classification: Roads and lanes, Sewage and drainage, Parks and greenery, Education and schools, and Garbage removal. We weight each spending category by slum dweller preferences. We use three measures of slum dweller preference to create three separate indices: the fraction of slum households in the city reporting (1) that the issue is the biggest problem in their area, (2) that it is a problem for them, or (3) that it is a problem for the community. For each weighting criteria, we calculate the sum of the logs of each weighted spending amount (wherever the value was zero it was bottom-coded to the first percentile of the spending distribution, prior to taking logs). The mean $z$-score of these three log-weighted spending measures serves as our pro-poor spending index. We also report the three log-weighted spending measures as separate outcomes.

The report card also reported councilors' assembly and committee attendance which were, on average, $81 \%$ and $66 \%$, respectively. Our second measure of councilor quality is an attendance index which is the mean $z$-score of attendance in: (1) MCD's general assembly and (2) MCD committees of which the councilor is a member. We focus on absolute committee attendance, without regard to the number of meetings per committee. The propoor spending index and the attendance index are positively correlated with $\rho=0.10$.

\section{Audit data from SSI}

All audits covered toilets and garbage points (dhalaos) and the second and third audit also covered drains. In each case, the auditor identified all alternatives. Auditors asked slum dwellers where they disposed of their trash and which public toilet they used. Any garbage disposal point or public toilet was audited when at least three residents reported using it.

\footnotetext{
${ }^{16}$ The categories were: (i) roads and lanes (construction and repair); (ii) sewage and drainage (including toilets); (iii) street lights; (iv) parks and greenery; (v) education and schools (improvement of MCD schools); (vi) garbage removal (supply of material, trucking; construction of garbage dumps; removal of malba (rubble)); and (vii) other. "Other" included: construction of MCD offices; improvements to staff quarters, katras (high-slum-index tenements), community centers, and health centers; construction of boundary walls; providing grills on chabuttras (monuments); and street name boards.)
} 
During a facility audit the surveyors noted its quality and interviewed two respondents to obtain data on frequency of cleaning and prices. For usage, the surveyor counted how many people used the toilet in a randomly chosen 15 minute interval between 3-5 PM.

\section{Electoral data}

For the April 2012 election we obtained ward-level electoral data: turnout, candidate list (with party) and candidate-wise vote-share. We also collected data on ward reservation status. For each incumbent councilor we coded a dummy which is equal to one if the quota rendered him ineligible for re-contest from his current ward. One third (80 of 240) of our incumbent councilors were ineligible.

Consistent with the idea that parties exercise choice in ticket allocation, the fraction of incumbents who did not re-run exceeds the fraction affected by quotas. Only two fifths (95 of 240) of incumbent councilors contested an election in any ward, including just over half (87 of 160) of those who were eligible to re-run in the same ward.

\subsection{Implementation and Balance Checks}

In late May and June 2010, mid-term report cards were published. Actual treatment was close to ITT: 109 of the 110 councilors were reported on, excluding one ward in which the councilor had died. In June 2010 letters were sent out to treatment councilors.

In March 2012, the second round of report cards was published. Newspaper space constraints resulted in actual treatment being significantly lower than ITT. 124 report cards were published: 45 of the $58 \mathrm{~T} 1$ wards and 79 of the $110 \mathrm{~T} 2$ wards. Across ITT councilors, we randomized the order in which report cards were published, but we prioritized report cards of councilors eligible for reelection. Data Appendix 8.2 provides details.

Throughout, we estimate ITT effects. Appendix Tables A.I and A.II provide balance checks. Panels A and B of Appendix Table A.I consider pre-treatment councilor spending outcomes (for 2007-09) for all wards and for slum-survey wards, respectively. Panel C considers slum households self-reports on problem areas over the last year. We observe no differences between treatment and control wards. Appendix Table A.II considers 2007 electoral outcomes as the dependent variable. We observe no differences between treatment and control wards for number of registered voters, turnout, seat reservation, or number of candidates, but $5.6 \%$ percentage points higher vote share among eligible treated councilors (significant at $10 \%$ ). 


\section{What to expect}

Political agency models assume that citizens infer a politician's type (say, how much she cares about the voter's welfare) from imperfectly observed politician actions. A politician's inferred type influences whether her party will select her to run again and whether voters subsequently vote for her. We discuss how, in such a setting disclosures - public or private - alter politician, party, and voter behavior.

\subsection{Impact on councilor behavior}

First, consider the newspaper disclosure treatment. Re-election concerns should cause a councilor to choose policies that result in a report card that appeals to party leaders and/or voters, assuming that she believes that these groups condition their choices on performance metrics in report cards. Presumably all voters want total spending of discretionary funds maximized. Meeting attendance should also be an unambiguous good, unless citizens favor councilor actions unobserved to us and there is a time budget constraint.

The effect on spending composition is less clear; slum residents and wealthier residents have different preferences, and incumbents' spending decisions, on average, favor wealthier residents and visible infrastructure. Given this, we evaluate a narrower hypothesis: in slumdense wards, treated councilors should better align spending decisions with the public good preferences of low-income voters. Such alignment is favored by the fact that newspaper report cards make it easier to transmit information about less visible but valued public goods to a broad population. By contrast, building a new park, a visible public good that RWA owners want, is expensive in land-scarce Delhi.

Both report card treatment arms should create incentive effects, though the additional credibility of T2 (midterm and pre-election report card) may plausibly increase its impact. ${ }^{17}$

In addition, the $\mathrm{T} 2$ treatment may have a councilor information effect if midterm report cards raise the salience of certain issues to councilors or provide them new information. For instance, since total spending in any single category reflects spending on multiple projects in different locations and years, councilors may not recognize the composition of their own spending and/or benchmark it correctly against spending by other councilors. On the other hand, this source of difference between T2 and T1 councilors is unlikely to be large; after all, T1 councilors could have collated the data to construct their own report cards.

\footnotetext{
${ }^{17}$ Avis et al. (2018) highlights the credibility effect by comparing municipalities that differ in whether, in addition to a pre-election corruption report, the municipality received a corruption report at start of term.
} 
Thus, a comparison of T1 and T2 may have limited power to disentangle the incentive and councilor information effects, especially since activism by citizens informed by the midterm report cards about councilor performance may strengthen T2 incentive effects.

In the private SSI experiment, we test the hypothesis that providing information just to the councilor can improve service delivery. The audit focused on public goods that correspond to slum dwellers' stated priorities (sanitation and garbage) and that lend themselves to simple improvements by a councilor: she could use discretionary funds to fix the toilets, monitor contractors who run the toilets, and pressure on municipal employees in charge of garbage collection. However, these also happen to be public goods where improvements are either less visible (repairing sewer systems) or require ongoing maintenance (toilets and garbage). If the councilors believe that a sufficient number of voters may not learn about their investments, then improving councilor information may not be enough to incentivize a councilor to improve performance.

\subsection{Impact on party and voter behavior when quotas exist}

By providing voters new information about their councilor or increasing its salience, newspaper report cards may change their voting preferences. Better performers should benefit, because voters will interpret good performance as indicative of a type that will also do more in the future. The one complication is if, knowing that a councilor was anticipating a report card, voters discount the signalling aspect of performance. In this case, a treated councilor with the same performance as a councilor in a control ward may attract less support (unless voters value the ability or willingness to respond to incentives). However, we have little reason to believe voters knew that politicians were forewarned.

Second, based on the incumbent's performance voters may conclude that the party does (or does not) care about voters like them.

Third, by informing party leaders about councilor performance, newspaper report cards could affect parties' rankings of councilors in terms of electability and contribution to positive party image. This should increase the likelihood that a high performing treated councilor receives a party ticket for the upcoming election.

Fourth, even if party leaders don't receive new information on a candidate, they may recognize that voters prefer high performers. This effect may be most important when voters do not know the candidate (e.g. because the candidate needs to change wards). A positive and credible report card is a good way to present a new candidate. We call this 
effect on the party selection process that happens even when the party learns nothing new, an advertisement effect.

In addition, by printing four report cards daily in 2012, the newspaper allowed voters to benchmark their councilor performance. Our baseline survey shows constituent pessimism about councilor spending: Of the $81 \%$ of slum households who answered a question on their councilor's relative performance, $71 \%$ thought he spent less money than other councilors. (9\% thought more, and 20\% thought about the same.) Thus, report cards could improve perceptions of a councilor, by showing that he was not performing relatively worse than the others. This should favor all treated councilors (unless voters extended inference to the untreated councilors). Further, it should encourage voters to benchmark their councilor's performance against those of others on the same page: controlling for actual performance, being a better performer among the four featured councilors should attract more votes. ${ }^{18}$

Expansion of gender quotas strengthened the party selection effect for incumbents who were rendered ineligible to run in their ward. The party had to decide whether to give these councilors a ticket from another ward; information that an ineligible councilor is a high-performer may sway the party decision.

Finally, turning to the SSI experiment, better performance based on improved information about where to invest in local public goods would benefit a councilor electorally only if a substantial number of voters and/or the party observe improvements in the quality of local public goods and attribute these improvements to the councilor. The localized and less visible nature of the investments highlighted in the audits makes it likely that, absent public disclosures, such information transmission doesn't occur.

\subsection{Summary of likely treatment impacts}

If councilors believe that newspaper report cards provide voters with information or make known information salient, then being treated should incentivize better performance. In high-slum wards, this should increase pro-poor spending. Informing only councilors (via audits) will similarly incentivize them only if they believe that a sufficient number of citizens or the party will learn about subsequent performance improvements.

New information or greater salience of known information should cause voters to favor better performers. With newspaper report cards, they should favor the better performers

\footnotetext{
${ }^{18}$ There is a potential countervailing effect: poor performance of all councilors may cause citizens to vote for someone outside of mainstream parties or depress turnout.
} 
among those published in the same newspaper edition.

The information and advertisement effects associated with newspaper report cards should lead parties to favor good performers in treatment wards when allocating party tickets. The advertisement effect is likely to be important in selecting which councilors to move to new wards where the voters do not know the candidate.

A well-performing incumbent's party should benefit from her performance. This is clear-cut where an incumbent's ineligibility requires the party to field a new candidate: the candidate will benefit from the party reputation. This is less obvious where the incumbent is eligible, because as we noted, a substantial fraction of eligible incumbents do not re-run presumably because parties want someone else. When a well-performing eligible incumbent gets replaced (say, because of internal party politics) voters may punish the party.

Finally, as incumbents' eligibility status was only determined four months before the election, we don't expect the incentive effects of the treatment to be influenced by a councilor's ultimate eligibility status.

\section{Does information influence councilor behavior?}

We start with the newspaper report card treatment and examine evidence on an incentive effect for councilors who anticipate performance disclosures prior to the election.

\subsection{Anticipated public disclosures: Newspaper report cards}

\section{A. Specification}

We consider ANCOVA specifications, which allow for smaller changes in wards with high baseline investments in that outcome, to estimate newspaper treatment effects in ward $w$ :

$$
\begin{gathered}
y_{w 1}=\alpha y_{w 0}+\beta \text { Treat }_{w}+X_{w}+\epsilon_{w} \\
y_{w 1}=\alpha y_{w 0}+\beta \text { Treat }_{w}+\gamma \text { High }_{w}+\lambda \text { Treat }_{w} \times \text { High }_{w}+X_{w}+\epsilon_{w}
\end{gathered}
$$


Treat $_{w}$ is ward treatment status, High $h_{w}$ is a high-slum ward indicator, Inelig $g_{w}$ is whether the councilor is ineligible for reelection in that ward, $X_{w}$ is a stratum fixed effect ( zoneparty combination), and other variables are described below. The main tables report ITT estimates where we pool the $T 1$ and $T 2$ treatment arms.

Our councilor performance measures $y_{w 1}$ include: log total spending, a pro-poor spending index, a councilor attendance index, and components of both indices. All outcomes are measured for post-treatment fiscal years 2010 and 2011. The lagged dependent variable, $y_{w 0}$ represents the average for pre-treatment fiscal years 2007-2009 of the same variables.

The equation (1) specification considers average treatment effects for the full sample. Equation( 2) examines heterogeneous treatment effects across high- and low-slum-density wards. A final source of random variation comes from quota-induced councilor ineligibility. Equation (3) examines what happens when we also control for eventual ineligibility.

\section{B. Results}

Table I presents our main specifications. Councilors typically spent their entire budget. Reflecting this, columns (1)-(3) show that anticipation of report cards has no effect on log total spending, estimated precisely, either on average or in high-slum wards. Councilor ineligibility for future elections also doesn't affect overall spending.

Columns (4)-(6) consider our primary incentive outcomes: the pro-poor spending index. The treatment impact on councilor spending depends on ward type: column (4) shows no overall treatment impact on spending. However, column (5) shows a large negative (but noisy) impact on pro-poor spending in low-slum wards, and relative to these treatment wards, a large positive impact on high-slum treatment wards (higher by $62 \%$ of a standard deviation). Column (6) shows that councilor ineligibility has no impact on nature of spending, in high- or low-slum wards. As a robustness check, Appendix Table A.VII presents specifications using an alternative definition for being high-slum: whether the ward was in our household survey sample. Recall that a survey selection criterion was (verified) slum density. Unsurprisingly, we see similar results to the main specification.

Appendix Table A.VI presents specifications where spending outcomes are individual spending categories. While the impacts are noisily estimated, treated councilors in highslum wards spent more on drainage and sewage - column (2) - and less on schools and parks - columns (4) and (6).

Columns (7)-(9) of Table I report on the attendance index. Interestingly, the pattern 
of impacts of report cards is similar to that on the spending index-the treatment effect on attendance in high-slum wards is significantly higher than that in low-slum wards. ${ }^{19}$ Ineligibility doesn't influence councilor behavior in high-slum wards. We find weak evidence that attendance of councilors from low-slum wards is negatively impacted by treatment. However, this is the only outcome where councilor ineligibility matters - given that, we read the evidence from Table I as consistent with the idea that uncertain future ineligibility had no impact on councilor behavior prior to elections.

In Appendix Table A.IV we separate T1 and T2 treatment arms - in general, we cannot reject identical impacts on the spending and attendance indices across the two arms, but $\mathrm{T} 2$ effects are more precisely estimated due to a larger sample.

\subsection{Private disclosures: State of Sanitation Information}

Councilors' policy response to anticipated newspaper disclosures is consistent with an incentive effect. The fact that $\mathrm{T} 1$ and $\mathrm{T} 2$ yield similar effects suggests that midterm report cards did not have any additional information or credibility effects. To further explore the relevance of a councilor information channel, we consider the private SSI experiment.

\section{A. Specification}

For comparison with Table I, we first estimate regressions of the same form as equation (2) where the treatment indicator is whether the councilor received an ssI report and outcome is pro-poor spending. Our sample is the 103 wards in the survey and audit sample.

Other than spending, councilors may improve public toilets and garbage piles via direct pressure on contractors responsible for their provision. We use the three rounds of audits to estimate slum-level difference-in-differences ITT regressions:

$$
\text { Service }_{s w}=\beta \text { Post }_{t} \times \text { Treat }_{s w}+\gamma \text { Post }_{t}+X_{w}+\epsilon_{s w},
$$

where Treat $_{s w}$ is the slum's ward treatment status, Post $t_{t}$ is a midline or endline audit

\footnotetext{
${ }^{19}$ Appendix Table A.V columns (3), (4), and (5) consider pro-poor spending index components, and show that findings are robust to the constituent preference weighting chosen. Columns (8) and (9) consider attendance index components: while patterns are similar, treatment effects are driven by assembly, rather than committee, attendance (even though multiple committees - including the slum development and ration committees - are relevant to low-income households). The difference in attendance effects across low- and high-slum neighborhoods is surprising - we would expect all citizens to favor more councilor involvement. It might reflect that the middle classes are more cynical about what politicians do.
} 
indicator, $X_{w}$ is a ward fixed effect, and Service $_{s w}$ are public services outcome variables.

\section{B. Results}

Table II presents private SSI disclosure results. For (ward-level) pro-poor spending we observe no significant impact of the SSI (column (1)). In contrast, columns (3) and (4) of Appendix Table A.VII show that, consistent with Table I results, newspaper report cards differentially raised pro-poor spending in treated wards for this sub-sample of wards.

Columns (2)-(9) consider impacts on audited outcomes (that featured in the SSI report received by councilors). Relative to control wards, slums in treatment wards show an insignificant decline in total toilets but a significant decline in the number of open usable toilets (columns (2) and (3)). While toilet prices are unaffected, the number of adult users declines in treatment wards (columns (4) and (5)). One possible explanation is that the councilor asked contractors to improve the worst toilets and they chose to close them. A less favorable view is that the councilor favored closing dirty toilets in order to improve apparent toilet quality and was less concerned with usage. We observe no impact of ssi treatment on either informal piles or formal garbage collection points (dhalaos) (columns (6)-(9)). On both toilets and garbage outcomes, there is no treatment heterogeneity due to councilor eligibility. Appendix Table A.VIII shows that the treatment also had no impact on total number of drains or their quality (as measured by the fraction of drains with disposal facilities and the fraction of drains that are clogged).

The absence of an impact of SSI treatment and similar impacts across the two newspaper treatment arms suggests that a direct lack of information did not constrain councilors.

\section{Does information influence party and voter behavior?}

Since the SSI treatment didn't influence councilor behavior, we focus our analysis of party and voter behavior on the newspaper treatment. ${ }^{20}$ This evaluation is of independent interest, and also helps identify whether councilors' response to the information disclosures could be justified by subsequent voter and party reactions.

\footnotetext{
${ }^{20}$ In analysis available from authors, we show that the ssi treatment did not affect party or voter behavior.
} 


\section{A. Specification}

Throughout, we report ITT estimates pooled across the two treatment arms. ${ }^{21}$ For each electoral outcome, we consider three specifications with increasing saturation. First, the average effect of report cards. Next, whether impacts differ by councilor eligibility status. Finally, a more descriptive specification to see whether councilor performance with respect to pro-poor spending and attendance influences party behavior.

$$
\begin{gathered}
\text { Outcome }_{w, c}=\text { BTreat }_{w, c}+X_{w}+\epsilon_{w, c} \\
\text { Outcome }_{w, c}=\beta_{1} \text { Treat }_{w, c} \times \text { Inelig }_{w}+\beta_{2} \text { Treat }_{w, c}+\gamma \text { Inelig }_{w}+X_{w}+\epsilon_{w, c} \\
\text { Outcome }_{w, c}=\beta_{i} \text { Treat }_{w, c} \times \text { Inelig }_{w} \times Y_{w, c}+\beta_{j} \text { Treat }_{w, c} \times Y_{w, c}+\gamma_{i} \text { Inelig }_{w} \times Y_{w, c}+\lambda_{i} Y_{w, c}+X_{w}+\epsilon_{w, c}
\end{gathered}
$$

${\text { where } \text { Treat }_{w, c} \text { is the ward/councilor treatment status, Inelig }}_{w}$ is whether the ward's councilor is ineligible for reelection in that ward, $Y_{w, c}$ is a vector of councilor's pro-poor spending index and attendance index. The identity, $X_{w}$ is a fixed effect for randomization stratum (the zone-party combination), and other variables are as described below.

We start with specifications where the councilor is the relevant unit: that is, treatment, ineligibility and performance outcomes are councilor-level characteristics that "follow" the councilor. For Outcome $_{c}$, we consider (1) whether she runs for re-election in any ward, (2) whether she runs in a different ward, (3) whether she runs in a different ward where the [retiring or ineligible] incumbent also belongs to her party, (4) her vote share (set to zero if she does not run), and (5) whether she wins an election in any ward.

We also report qualitatively distinct specifications which consider incumbent party electoral outcomes as the ward-level outcome variables, Outcome $e_{w}$. The treatment impact on the incumbent can entirely reflect a party selection effect: if the party uses report cards to select who re-runs, we will see an effect on treated incumbents. In other words, even if support among voters for every single incumbent is unaffected by treatment, a party's use of the report card to allocate tickets can generate a positive incumbent level treatment effect. It will not, however, generate a ward level treatment effect. The latter is only possible if the report card alters preferences of voters targeted by the policy. This is, therefore, the only way we have to tell whether report cards affected voter preferences, and, if so, how.

Finally we report specifications that consider councilor performance relative to other

\footnotetext{
${ }^{21}$ Impacts across treatment arms are qualitatively similar. Results available from authors.
} 
councilors who featured in the same newspaper issue, controlling for their actual pro-poor spending. Do other councilors' report card serve as a yardstick? We estimate TOT estimates for the 124 councilors whose report cards were actually published in newspapers:

Outcome $_{c}=\beta_{1}$ Inelig $_{c} \times$ Rank $_{c}+\beta_{2}$ Date $_{c} \times$ Rank $_{c}+\beta_{3}$ Rank $_{c}+\gamma_{1}$ Inelig $_{c}+\gamma_{2}$ Date $_{c}+Y_{c}+X_{c}+\epsilon_{c}$,

where $R a n k_{c}$ is the rank of the councilor's pro-poor spending index across the four councilors featured in the same newspaper issue, Date $_{c}$ is the publication date of the newspaper issue containing the councilor's report card, $Y_{c}$ is a vector of the councilor's pro-poor spending index and the spending index interacted with ineligibility and with publication date, and other variables are as defined above. Publication date is included as a control because, as mentioned, the publication of report cards for eligible councilors were prioritized.

\section{B. Results}

$48 \%$ of eligible incumbents in control wards ran for re-election. Column (1) of Table III shows that treated incumbents were 12 percentage points more likely to receive a party nomination to contest re-election. In contrast, column (2) shows that the magnitude of the treatment effect for the ineligible, while more than twice as large as that for the eligible, is not statistically different from that for the eligible. (The latter estimate a non-trivial 7 percentage points, though not statistically different from zero.) That said, no ineligible councilor from a control ward ran for re-election. The impact of treatment on ticket allocation for ineligible councilors becomes clear when we consider whether the councilor ran in a different ward. We observe a treatment effect only among ineligible councilors: column (4) shows that the treatment-induced increase in contesting elections from a different ward comes entirely from ineligible councilors who contest elections in new wards. In other words, eligible incumbent councilors either re-run in their current ward or fail to get a party ticket. Finally, columns (5) and (6) show that councilors who run in a new ward tend to displace incumbents from the same party, and this group consists of ineligible councilors.

Just eight ineligible councilors received a party ticket for another ward. To address small sample concerns, we also report $p$-values estimated with randomization inference. The randomization inference $p$-value of treated councilors receiving a party nomination remains significant at $10 \%$, and the key factor driving this - the treatment effect on ineligible councilors contesting from different wards - remains significant at $5 \%$. We continue to 
observe that this is driven by parties reassigning tickets for wards they already control.

This points to a selection process where the party uses report cards to select which ineligible incumbents to give a ticket elsewhere. The party appears less inclined to move eligible councilors elsewhere; either there is an argument to keep them in their own ward and should stay there, or, if they are unpopular, they are unlikely to be worth moving, especially relative the entire pool of ineligible councilors. The latter group are randomly selected (by assignment of the quotas) and, therefore, contain some of the best performing incumbents.

In Table IV we directly examine party selection based on performance on the report cards. We see these results as an important consistency check on our results, while recognizing that the pro-poor spending index variable is not exogenous. In column (1) we see that the impact of spending performance on ticket allocation is heterogeneous across eligible and ineligible councilors. Specifically, a better pro-poor spending record makes ineligible treated incumbents more likely to receive a ticket: for each standard deviation increase in their pro-poor spending record ineligible treated incumbents are 23 percentage points more likely to be given a ticket. There is no similar effect among eligible treated incumbents, or among eligible councilors in the control group. ${ }^{22}$ In other words, eligible incumbents with high pro-poor spending do not benefit from newspaper report cards, possibly because voters already have enough information about them.

Consistent with the idea that parties want councilors to be responsive to constituent needs, columns (2) and (3) provide suggestive evidence that parties favor giving tickets to ineligible councilors in high-slum wards with high pro-poor spending, but not to those in low-slum wards with high pro-poor spending. In contrast, we continue to see some evidence that good attendance benefits ineligible councilors in low-slum wards. We should caveat these findings by the observation that the impacts are statistically similar across high and low-slum wards.

Columns (5) and (6) find that only ineligible councilors with high pro-poor spending from high-slum wards get to move to a different ward. On the margin, ineligible treated incumbents from high-slum wards are 29 percentage points more likely to be given a ticket to run elsewhere, for each standard deviation increase in their pro-poor spending record. Those with a similarly good spending record from low-slum wards do not get the same

\footnotetext{
${ }^{22}$ The pro-poor spending coefficient for the control group is +8 percentage points, $p=0.39$, omitted from the table for space but available from the authors. However, among control councilors from high-slum wards, this coefficient is +21 percentage points, $p=0.15$. Of course this trend is non-experimental.
} 
advantage, though there are too few such councilors to be able to say anything definitive about this comparison.

Columns (8) and (9) show that that parties favor moving ineligible councilors with high pro-poor spending into new party-controlled wards that are high-slum wards, which makes sense since the evidence that they have to advertise relates to performing well in high-slum wards. On the margin, ineligible treated incumbents are 21 percentage points more likely to be given a ticket to run in another high-slum ward controlled by their party for each standard deviation increase in their pro-poor spending record.

To summarize, parties retain ineligible councilors who had a good performance record in serving their own low-income ward and field them in other slum-dense wards. These benefits do not accrue to untreated ineligible councilors, even if they have high pro-poor spending, suggesting either that parties only have access to the spending information through the media, or that parties value the credibility associated with publication in a newspaper.

Taken together, these results suggest that councilors were correct to respond to the electoral incentives provided by report cards since, conditional on being rendered ineligible, a good report card helped them get a party ticket. Those who get to run should also get more votes and should be more likely to win. Table V confirms this, and documents a sizeable advantage for high pro-poor spenders in treated high-slum wards. Column (1) shows a 5 percentage point rise in the vote share of councilors who received a report card. Column (2) shows that this impact might be slightly larger for ineligible councilors. Column (3) suggests that treated ineligible councilors (who necessarily run elsewhere if they run at all) gain more in vote share if their pro-poor spending is higher. Once again this is not true of treated eligible councilors relative to eligible councilors in the control group, or among eligible councilors in the control group. ${ }^{23}$ On the margin, ineligible treated incumbents earn 10 percentage points higher vote share for each standard deviation increase in their pro-poor spending record. This suggests that a positive report card is beneficial for councilors to earn votes from less familiar voters.

Columns (4)-(5) show that the effect is concentrated among councilors who came from high-slum wards, so that their pro-poor spending would have been aligned with the preferences of their former constituents. On the margin, ineligible treated incumbents from high-slum wards earn 21 percentage points higher vote share for each standard deviation

\footnotetext{
${ }^{23}$ The pro-poor spending coefficient for the control group is +4 percentage points, $p=0.25$, omitted from the table for space but available from the authors. However, among control councilors from high-slum wards, this coefficient is +10 percentage points, $p=0.09$. Once again, this trend is non-experimental.
} 
increase in their pro-poor spending record. Columns (6)-(10) show a similar pattern for winning elections, but the binary outcome results in noisier estimates. In particular, on the margin, ineligible treated incumbents from high-slum wards are 49 percentage points more likely to win an election for each standard deviation increase in their pro-poor spending record. Appendix Table A.XI shows that the treatment didn't affect voter registration or turnout.

Table VI presents ward-level results for electoral outcomes - that is, electoral rewards that might accrue to a party even if their incumbent councilor departs. As we mentioned earlier, this is direct evidence on whether the treatment altered voter preferences. Column (1) and (2) show that there is no residual vote share benefit for the party from simply having had a report card published, but column (3) shows that in wards where the incumbent can't re-run, there is a benefit for having had a report card published showing high pro-poor spending, and columns (4)-(5) confirm that this effect is driven by high-slum wards. On the margin, a party earns 10 percentage points higher vote share for each standard deviation increase in the pro-poor spending record of a treated, ineligible incumbent. As in Table V, columns (6)-(10) show a similar pattern for winning election, but the binary outcome results in noisier estimates. High levels of pro-poor spending in high-slum wards, when reported in the newspaper, increases support among voters for the incumbent's party in wards where the incumbent can't re-run. Once again this suggests that voters have a different relation with eligible incumbents; perhaps they already know what they like (and dislike) about them (which may or may not be reflected in the report card). Moreover, when eligible incumbents did not get a ticket (which was quite common), the voters might have held it against the party, especially if the incumbent had a good report card. This could explain what we see in column (4) in Table VI: that in high-slum wards with eligible treated incumbents, getting a good report card reduces the party's vote share, though it could also be something accidental.

Table VII presents councilor-level results for the "yardstick" results - whether it helps councilors who performed well relative to others featured in the same newspaper issue. Columns (1), (2), and (4) show a yardstick effect on the party decision to run an ineligible councilor in a different ward. For each rank (out of four) that an ineligible councilor drops with respect to pro-poor spending, the party is 32 percentage points less likely to give that councilor a ticket to run. Column (4) shows that for each drop in rank, the vote share of an ineligible councilor from a high-slum ward goes down by 15 percentage points. 


\section{Conclusion}

This paper provides evidence on the impact of public and private information disclosures on choices made by councilors, political parties, and voters.

Anticipation of public disclosures motivated councilors representing high-slum wards to better align spending priorities with their constituents. In a setting where a significant fraction of them would be ineligible to run from their current ward, they were right to do so. Parties are more likely to give tickets to treated councilors from high-slum wards, who, according to their report cards, had served slum dwellers well. Among such high-performing incumbents, those who were rendered ineligible to run from their current ward because of gender quotas benefited, and got to run and win from other wards. These effects are large; ineligible treated incumbents from high-slum wards are 29 percentage points more likely to receive a ticket to run elsewhere, for each standard deviation increase in their pro-poor spending record. Finally, voters in high-slum wards also reward the party associated with high-performing incumbents who got a report card.

On the other hand, disclosing information privately to politicians has no discernible positive effects on their spending priorities or provision of public infrastructure in slums. We posit that, absent a dissemination mechanism like newspapers, councilors failed to anticipate electoral benefits from investments in valued but less visible local public goods.

Quota-induced ineligibility mimics, in many ways, term limits for politicians, which are common in middle- and lower-income countries. Furthermore, it is common for termlimited politicians to seek other political offices. Our findings suggest that public disclosures could be valuable for this group, especially since they do not face electoral accountability pressures in their current seat.

In the absence of credible public disclosures, politicians and even parties may lack incentives to act in the interests of voters. Conversely, in a time of increasing financial pressure, credible print or online media may lack financial incentives to publish this information. We argue that to support a better functioning democracy, there is a need to explore how independent institutions that could perform this role can be formed and funded. Put differently, this suggests an important direction for future research: Is there some way to provide the public with credible performance information on a routine basis, and get them to pay attention to it, without actually printing report cards in the newspaper before the election? 


\section{References}

Avis, E., C. Ferraz, and F. Finan (2018). Do government audits reduce corruption? Estimating the impacts of exposing corrupt politicians. Journal of Political Economy 126(5), $1912-1964$.

Banerjee, A., S. Kumar, R. Pande, and F. Su (2011). Do informed voters make better choices? Experimental evidence from urban India. Unpublished.

Beaman, L., R. Pande, and A. Cirone (2012). Politics as a Male Domain and Empowerment in India, Chapter 13, pp. 208-226. Oxford University Press.

Besley, T. and R. Burgess (2002). The political economy of government responsiveness: Theory and evidence from India. The Quarterly Journal of Economics 117(4), 14151451.

Besley, T., O. Folke, T. Persson, and J. Rickne (2017). Gender quotas and the crisis of the mediocre man: Theory and evidence from Sweden. American Economic Review 107(8), $2204-42$.

Bidwell, K., K. Casey, and R. Glennerster (2019). Debates: oting and expenditure responses to political communication. Journal of Political Economy. Forthcoming.

Bobonis, G. J., L. R. Cámara Fuertes, and R. Schwabe (2016, August). Monitoring corruptible politicians. American Economic Review 106(8), 2371-2405.

Chong, A., A. L. De La O, D. Karlan, and L. Wantchekon (2014). Does corruption information inspire the fight or quash the hope? A field experiment in Mexico on voter turnout, choice, and party identification. The Journal of Politics 77(1), 55-71.

Cruz, C., P. Keefer, and J. Labonne (2016). Incumbent advantage, voter information and vote buying. Technical report, IDB Working Paper Series.

Delhi Human Development Report (2006). Oxford University Press, New Delhi.

Dunning, T., G. Grossman, M. Humphreys, S. D. Hyde, C. McIntosh, G. Nellis, C. L. Adida, E. Arias, C. Bicalho, T. C. Boas, M. T. Buntaine, S. Chauchard, A. Chowdhury, J. Gottlieb, F. D. Hidalgo, M. Holmlund, R. S. Jablonski, E. Kramon, H. Larreguy, M. Lierl, J. Marshall, G. McClendon, M. A. Melo, D. L. Nielson, P. M. Pickering, M. Platas, 
P. Querubin, and N. Sircar (2019). Voter information campaigns and political accountability: Cumulative findings from a preregistered meta-analysis of coordinated trials. Science Advances 5(7).

DUSIB (2010). The Delhi Urban Shelter Improvement Board act. http:// delhishelterboard.in/main/wp-content/uploads/2012/02/DUSIB-ACT-2010 . pdf.

Ferraz, C. and F. Finan (2008). Exposing corrupt politicians: The effects of Brazil's publicly released audits on electoral outcomes. The Quarterly Journal of Economics 123(2), 703745 .

Fujiwara, T. and L. Wantchekon (2013). Can informed public deliberation overcome clientelism? Experimental evidence from Benin. American Economic Journal: Applied Economics 5(4), 241-55.

Government of National Capital Territory of Delhi (2014, Mar). Bhagidari. http://delhi.gov.in/wps/wcm/connect/doit_shahdara/Shahdara/Home/ RWAandBhagidari/Bhagidari.

Grossman, G. and K. Michelitch (2018). Information dissemination, competitive pressure, and politician performance between elections: A field experiment in Uganda. American Political Science Review 112(2), 280-301.

IL \& FS Ecosmart Limited (2006). City development plan: Delhi. Ministry of Urban Development, Government of National Capital Territory of Delhi. Submitted under JNNURM.

International Budget Partnership (2010, Jan). Constituency development funds: Scoping paper. Technical report.

Kendall, C., T. Nannicini, and F. Trebbi (2015, January). How do voters respond to information? Evidence from a randomized campaign. American Economic Review 105(1), 322-53.

Lehne, J., J. N. Shapiro, and O. Vanden Eynde (2018). Building connections: Political corruption and road construction in india. Journal of Development Economics 131, 6278.

Mendel, T. D. (2014). Right to information: Recent spread of RTI legislation. Technical report, World Bank Group. 
Snyder Jr, J. M. and D. Strömberg (2010). Press coverage and political accountability. Journal of Political Economy 118(2), 355-408.

Strömberg, D. (2004). Mass media competition, political competition, and public policy. The Review of Economic Studies 71(1), 265-284.

Wantchekon, L. (2003). Clientelism and voting behavior: Evidence from a field experiment in Benin. World Politics 55(3), 399-422.

\section{Data Appendix}

\subsection{Slum Identification}

We identify slums following a methodology based on the UN-HABITAT and Indian census definition of slums. ${ }^{24} \mathrm{~A}$ list of nine common criteria closely correlated to the census definition of slums was drawn up and included high density of housing, poor quality housing structure and material, lack of internal household infrastructure, poor road infrastructure, access to water and water infrastructure, uncovered and unimproved drains, low coverage of private toilet facilities, high incidence of trash piles and frequent cohabitation with animals. ${ }^{25}$

We used a two-stage process: first, we compiled a list of potential areas from inspection of the visual appearance from aerial photographs of Delhi using satellite imagery, based on housing density and appearance, complemented by Delhi government listings. This was

\footnotetext{
${ }^{24}$ The 2011 Indian census defines a slum as a "compact housing cluster or settlement of at least 20 households with a collection of poorly built tenements which are, mostly temporary in nature with inadequate sanitary, drinking water facilities and unhygienic conditions will be termed as slums."; UN-HABITAT defines a slum household as "a group of individuals living under the same roof that lacks any one of meet the following conditions: insecure residential status, inadequate access to safe water, inadequate access to sanitation and other infrastructure, poor structural quality of housing and overcrowding." The main difference between the two is UN-HABITAT's inclusion of insecure residential status; this is an issue that will be explored within the survey work, but since this is the case to some degree in most Delhi slums, we safely omit it.

${ }^{25}$ Housing: Whether the space separating households was sufficiently wide for vehicles larger than motorcycles; housing materials: Whether the majority of houses are made of unimproved brick or lower quality material, including metal and plastic sheeting; internal household infrastructure: Whether household chores (e.g. washing, cooking) were frequently done outside of the house as a proxy for the quality of households' internal infrastructure, since households who conduct these activities outside tend to lack household water supply/drainage or ventilation for cooking smoke; road infrastructure: Whether the majority of roads in the area were unpaved, badly maintained, and of poor quality; water: Whether households receive water from hand pumps, tanker trucks, or lower-grade options; animal cohabitation: Whether non-domestic animals (buffalo, goats, pigs, donkeys) resided in the same tenements as people.
} 
then verified by field visits; locations that prominently featured at least five of these nine characteristics were marked as more slummy and others as less slummy.

Between 9 and 126 households were surveyed in each ward ${ }^{26}$, with the exact number in a slum dependent on the number of potential slums identified by satellite image in each ward and the physical size of the slum. To the extent that population density is similar across different slums, this approximates a Probability Proportional to Size (PPS) sampling procedure. To select households within slums we also used a spatial method: an overall map of each slum was created, and then surveyors were stationed at randomly selected points within the slums. Surveyors then followed the "right hand rule," where each surveyor moves from their start point along the right hand side of the wall, interviewing every $\mathrm{X}$ households (where $\mathrm{X}$ is determined by the population of the slum).

Overall, we had just over 3,400 households in high-slum areas and 2,000 households in 8 low-slum neighborhoods (fewer than five slum characteristics). ${ }^{27}$

\subsection{Newspaper Report Card Publication Sequence Randomization}

All 2010 report cards were published as intended, but subject to space constraints in each newspaper and time constraints, we were unable to publish all 2012 report cards before the 2012 election. We did not publish any report cards after election day. Of 168 report cards for ITT councilors, 124 were published. Six wards were dropped because the councilor was suspended for corruption or died; seven were dropped because they were never sampled (in two of these cases another ward was sampled instead); one was dropped because there were no slums in the ward; and the last thirty were dropped because they could not be published by election day. Out of the $58 \mathrm{~T} 1$ wards, 45 were treated, and of the $110 \mathrm{~T} 2$ wards, 79 were treated.

First, report cards were categorized according to zone (of which there were ten), to whether the councilor was eligible for reelection, and to whether the ward had above- or below-median slum fraction by area. Then, within these forty categories, each of which had

\footnotetext{
${ }^{26}$ In ten wards, it was found that surveys had been conducted in the wrong areas. In these cases, surveyors were sent back out, and the surveys were redone in the proper areas. In some cases, the incorrect surveys were still conducted in slum areas, so have been included in the data; thus ten wards have sixty or more surveys. In other cases, the wrongly done surveys were dropped.

${ }^{27}$ The survey was typically carried out with the household head (in $51 \%$ of the cases) or, in the case where the household head was unavailable or away on two consecutive visits made to the household, with his or her spouse ( $49 \%$ of the cases) or other household member. If a household proved unwilling or unavailable after multiple visits, another was selected using the same method.
} 
about four report cards, we randomly assigned report cards to pairs. We then assigned a stratum to each pair according to treatment status (T1/T1, T1/T2, or T2/T2) and political party affiliation (no BJP councilor, or at least one BJP councilor). We randomly assigned publication sequence to each pair of report cards for eligible councilors, distributing the above six strata evenly across the publication sequence. Then we repeated the process for half (i.e. as many as possible) of the report cards for ineligible councilors, and these were placed after the eligible councilors in the publication sequence. Report cards for ineligible councilors were published after the deadline for parties to assign candidate tickets. Two pairs of report cards were published in each daily issue of the newspaper.

\subsection{State of Sanitation Information Randomization}

Our audits covered the sample of 108 high-slum wards that entered our baseline survey. These wards, in turn, were situated in 55 state assembly constituencies (ACs). All ACs were randomized into treatment and control, followed by a balanced randomization of the wards within an AC. In the event that a ward was split across two ACs, it was put in the AC with an unbalanced number of wards. We then separately randomized report card distribution across the two levels of government: 51 wards were randomly assigned to have the MCD councilor receive a ward report card and, out of the 55 ACs, 27 were randomly assigned to receive a AC report cards. ${ }^{28}$ In each ward we audited, on average, three slums giving us a sample of 310 slums across 108 wards.

\footnotetext{
${ }^{28}$ Because Wards and ACs are not perfectly aligned, this made for a total of 118 Ward-AC combinations: 30 control, 30 where only the MLA received a report card, 32 where only the MCD councilor received a report card, and 26 were both the MLA and MCD councilor received report cards.
} 


\section{Tables}

Table I: Effect of any newspaper report card treatment on MCD councilor spending according to slum preferences and attendance

\begin{tabular}{|c|c|c|c|c|c|c|c|c|c|}
\hline & \multicolumn{3}{|c|}{$\begin{array}{l}\text { Log total } \\
(2010-12)\end{array}$} & \multicolumn{3}{|c|}{$\begin{array}{l}\text { Pro-poor spending in- } \\
\operatorname{dex}(2010-2012)\end{array}$} & \multicolumn{2}{|c|}{$\begin{array}{l}\text { Attendance } \\
(2010-12)\end{array}$} & \multirow{2}{*}{$\begin{array}{r}\text { index } \\
(9)\end{array}$} \\
\hline & $(1)$ & $(2)$ & $(3)$ & $(4)$ & $(5)$ & $(6)$ & $(7)$ & $(8)$ & \\
\hline Treatment $\times$ High slum & & $\begin{array}{l}-0.049 \\
(0.074)\end{array}$ & $\begin{array}{l}-0.097 \\
(0.100)\end{array}$ & & $\begin{array}{l}0.617^{* *} \\
(0.288)\end{array}$ & $\begin{array}{l}0.752^{* *} \\
(0.373)\end{array}$ & & $\begin{array}{r}0.372^{*} \\
(0.196)\end{array}$ & $\begin{array}{c}0.128 \\
(0.225)\end{array}$ \\
\hline Treatment & $\begin{array}{c}0.005 \\
(0.040)\end{array}$ & $\begin{array}{c}0.050 \\
(0.057)\end{array}$ & $\begin{array}{c}0.051 \\
(0.081)\end{array}$ & $\begin{array}{l}-0.010 \\
(0.133)\end{array}$ & $\begin{array}{l}-0.309 \\
(0.201)\end{array}$ & $\begin{array}{l}-0.384 \\
(0.278)\end{array}$ & $\begin{array}{c}0.030 \\
(0.100)\end{array}$ & $\begin{array}{l}-0.227 \\
(0.138)\end{array}$ & $\begin{array}{c}0.006 \\
(0.147)\end{array}$ \\
\hline Ineligible $\times$ Treatment $\times$ High slum & & & $\begin{array}{c}0.115 \\
(0.160)\end{array}$ & & & $\begin{array}{l}-0.479 \\
(0.618)\end{array}$ & & & $\begin{array}{c}0.694 \\
(0.497)\end{array}$ \\
\hline Ineligible $\times$ Treatment & & & $\begin{array}{c}0.035 \\
(0.119)\end{array}$ & & & $\begin{array}{c}0.255 \\
(0.425)\end{array}$ & & & $\begin{array}{r}-0.668^{*} \\
(0.368)\end{array}$ \\
\hline Remaining interactions & No & Yes & Yes & No & Yes & Yes & No & Yes & Yes \\
\hline Pre-treat outcome control & Yes & Yes & Yes & Yes & Yes & Yes & Yes & Yes & Yes \\
\hline Strata (zone-party) FE & Yes & Yes & Yes & Yes & Yes & Yes & Yes & Yes & Yes \\
\hline Pre-treat control mean & 5.709 & 5.721 & 5.721 & -0.000 & 0.019 & 0.019 & 0.000 & -0.004 & -0.004 \\
\hline Pre-treat control s.d. & 0.157 & 0.109 & 0.109 & 1.000 & 0.923 & 0.923 & 0.893 & 0.912 & 0.912 \\
\hline$p$-value: $T \times H i g h+T+H i g h=0$ & & 0.994 & & & 0.722 & & & 0.453 & \\
\hline$p$-value: $T \times H i g h+T+H i g h=T$ & & 0.254 & & & 0.012 & & & 0.248 & \\
\hline$p$-value: $T \times H i g h+T+H i g h=H i g h$ & & 0.977 & & & 0.123 & & & 0.301 & \\
\hline Observations & 240 & 227 & 227 & 240 & 227 & 227 & 240 & 227 & 227 \\
\hline
\end{tabular}

Heteroskedasticity-robust standard errors in parentheses. ${ }^{*} p<.10,{ }^{* *} p<.05,{ }^{* * *} p<.01$.

Ward-level OLS regression. Pro-poor spending index components are each log spending on issues, with each issue weighted by the fraction of slum households in the city reporting that (1) it is the most problematic in the area, (2) it is a problem for them, and (3) it is a problem for the community. Attendance index components are councilor attendance at (1) the general assembly and (2) councilor committee meetings. "Treatment" indicates observations of a ward in which a report card on the performance of the MCD councilor was published in a newspaper during the 2012 pre-election period (T1 or T2, ITT). Spending is categorized by lexical heuristic. 
Table II: Effect of State of Sanitation Information on public services

\begin{tabular}{|c|c|c|c|c|c|c|c|c|c|}
\hline & $\begin{array}{l}\quad(1) \\
\text { Pro-poor } \\
\text { spending } \\
\text { index }\end{array}$ & $\begin{array}{l}\text { Total } \\
\text { toilets }\end{array}$ & $\begin{array}{l}(3) \\
\text { Open } \\
\text { toilets }\end{array}$ & $\begin{array}{l}\text { (4) } \\
\text { Toilet } \\
\text { price }\end{array}$ & $\begin{array}{c}(5) \\
\text { Adult } \\
\text { toilet } \\
\text { users (\#) }\end{array}$ & $\begin{array}{c}\text { (6) } \\
\text { Total } \\
\text { dhalaos }\end{array}$ & $\begin{array}{c}(7) \\
\text { Dhalaos } \\
\text { regularly } \\
\text { collected }(\%)\end{array}$ & $\begin{array}{c}\text { (8) } \\
\text { Total } \\
\text { informal piles }\end{array}$ & $\begin{array}{c}(9) \\
\text { Informal piles } \\
\text { recently } \\
\text { collected }(\%)\end{array}$ \\
\hline SSI treatment & $\begin{array}{c}-0.049 \\
(0.190)\end{array}$ & & & & & & & & \\
\hline Post $\times$ SSI treatment & & $\begin{array}{l}-0.125 \\
(0.133)\end{array}$ & $\begin{array}{c}-0.204^{* *} \\
(0.090)\end{array}$ & $\begin{array}{c}0.065 \\
(0.108)\end{array}$ & $\begin{array}{c}-1.931^{*} \\
(0.996)\end{array}$ & $\begin{array}{c}-0.087 \\
(0.058)\end{array}$ & $\begin{array}{l}-0.004 \\
(0.089)\end{array}$ & $\begin{array}{c}1.310 \\
(2.209)\end{array}$ & $\begin{array}{l}-0.038 \\
(0.044)\end{array}$ \\
\hline Post & & $\begin{array}{l}0.280^{* *} \\
(0.112)\end{array}$ & $\begin{array}{c}0.206^{* *} \\
(0.081)\end{array}$ & $\begin{array}{c}0.047 \\
(0.061)\end{array}$ & $\begin{array}{c}1.389 \\
(0.847)\end{array}$ & $\begin{array}{l}0.196^{* * *} \\
(0.049)\end{array}$ & $\begin{array}{l}-0.054 \\
(0.065)\end{array}$ & $\begin{array}{c}-3.236^{* *} \\
(1.365)\end{array}$ & $\begin{array}{l}0.416^{* * *} \\
(0.026)\end{array}$ \\
\hline Ward FE & No & Yes & Yes & Yes & Yes & Yes & Yes & Yes & Yes \\
\hline Strata (zone-party) FE & Yes & No & No & No & No & No & No & No & No \\
\hline Pre-treat outcome control & Yes & No & No & No & No & No & No & No & No \\
\hline Baseline control mean & 0.102 & 2.718 & 1.859 & 0.973 & 9.994 & 0.436 & 0.304 & 19.207 & 0.253 \\
\hline Observations & 103 & 932 & 932 & 430 & 932 & 932 & 328 & 867 & 867 \\
\hline
\end{tabular}

Heteroskedasticity-robust standard errors in parentheses. ${ }^{*} p<.10,{ }^{* *} p<.05,{ }^{* * *} p<.01$.

Slum-level OLS regression. "SSI treatment" indicates observations in a slum of which the MCD councilor received State of Sanitation Information (ITT). "Post" indicates observations that took place in the second or third round of audits. "Total informal piles" is the number of informal garbage piles in the slum. "Informal piles not recently collected" is the fraction of informal garbage piles in the slum not collected in the past week. "Total dhalaos" is the number of dhalaos (formal garbage collection points) in the slum. "Dhalaos regularly collected" is the fraction of dhalaos in the slum regularly collected, relative to the number of dhalaos at the baseline. 529 of 932 slums have a public toilet. "Closed toilets" is the number of closed toilets in the slum. "Toilet price" is the average price of toilets in the slum. "Adult users (\#)" is the number of adult toilet users in the slum. 
Table III: Effect of newspaper report card publication on councilor-level electoral outcomes

\begin{tabular}{|c|c|c|c|c|c|c|}
\hline & \multicolumn{2}{|c|}{$\begin{array}{l}\text { Councilor runs } \\
\text { in any ward }\end{array}$} & \multicolumn{2}{|c|}{$\begin{array}{l}\text { Councilor runs } \\
\text { in other ward }\end{array}$} & \multicolumn{2}{|c|}{$\begin{array}{l}\text { Councilor runs } \\
\text { in other ward } \\
\text { controlled by party }\end{array}$} \\
\hline & (1) & $(2)$ & $(3)$ & $(4)$ & $(5)$ & (6) \\
\hline \multirow[t]{3}{*}{ Treatment $\times$ Ineligible } & & 0.091 & & $0.156^{* * *}$ & & $0.116^{* *}$ \\
\hline & & $(0.114)$ & & $(0.056)$ & & $(0.050)$ \\
\hline & & {$[0.454]$} & & {$[0.050]$} & & {$[0.103]$} \\
\hline \multirow[t]{3}{*}{ Treatment } & $0.120^{*}$ & 0.071 & $0.039^{*}$ & -0.012 & $0.044^{* *}$ & 0.007 \\
\hline & $(0.067)$ & $(0.086)$ & $(0.022)$ & $(0.019)$ & $(0.018)$ & $(0.014)$ \\
\hline & {$[0.100]$} & {$[0.404]$} & {$[0.186]$} & {$[0.630]$} & {$[0.101]$} & {$[0.891]$} \\
\hline \multirow[t]{3}{*}{ Ineligible } & & $-0.473^{* * *}$ & & -0.028 & & -0.009 \\
\hline & & $(0.079)$ & & $(0.022)$ & & $(0.016)$ \\
\hline & & {$[0.247]$} & & {$[0.784]$} & & {$[0.935]$} \\
\hline Strata (zone-party) FE & Yes & Yes & Yes & Yes & Yes & Yes \\
\hline Ineligible control mean & 0.000 & 0.000 & 0.000 & 0.000 & 0.000 & 0.000 \\
\hline Eligible control mean & 0.478 & 0.478 & 0.022 & 0.022 & 0.000 & 0.000 \\
\hline Observations & 240 & 240 & 240 & 240 & 240 & 240 \\
\hline
\end{tabular}

Heteroskedasticity-robust standard errors in parentheses. ${ }^{*} p<.10,{ }^{* *} p<.05,{ }^{* * *} p<.01$.

Councilor-level cross section estimated with OLS and with randomization inference (10,000 repetitions). Robust standard errors in parentheses. Randomization inference $p$-values in brackets. Randomization strata are fixed. 
Table IV: Effect of newspaper report card publication, attendance, and spending on councilor-level electoral outcomes, by ward slumminess

\begin{tabular}{|c|c|c|c|c|c|c|c|c|c|}
\hline & \multicolumn{3}{|c|}{$\begin{array}{l}\text { Councilor runs } \\
\text { in any ward }\end{array}$} & \multicolumn{3}{|c|}{$\begin{array}{l}\text { Councilor runs } \\
\text { in other ward }\end{array}$} & \multicolumn{3}{|c|}{$\begin{array}{l}\text { Councilor runs } \\
\text { in other ward } \\
\text { controlled by party }\end{array}$} \\
\hline & $(1)$ & $\begin{array}{l}\text { (2) } \\
\text { from high- } \\
\text { slum ward }\end{array}$ & $\begin{array}{l}\text { (3) } \\
\ldots \text { from low- } \\
\text { slum ward }\end{array}$ & $(4)$ & $\begin{array}{l}\text { (5) } \\
\ldots \text { from high- } \\
\text { slum ward }\end{array}$ & $\begin{array}{c}(6) \\
\ldots \text { from low- } \\
\text { slum ward }\end{array}$ & $(7)$ & $\begin{array}{l}\text { (8) } \\
\ldots \text { to high- } \\
\text { slum ward }\end{array}$ & $\begin{array}{l}\text { (9) } \\
\ldots \text { to low- } \\
\text { slum ward }\end{array}$ \\
\hline $\begin{array}{l}\text { Treatment } \times \text { Ineligible } \times \ldots \\
\quad \ldots \text { Pro-poor Spending Index }\end{array}$ & $\begin{array}{r}0.229^{*} \\
(0.118)\end{array}$ & $\begin{array}{c}0.414^{*} \\
(0.213)\end{array}$ & $\begin{array}{c}0.136 \\
(0.155)\end{array}$ & $\begin{array}{l}0.125^{* *} \\
(0.058)\end{array}$ & $\begin{array}{l}0.291^{* *} \\
(0.136)\end{array}$ & $\begin{array}{c}0.084 \\
(0.068)\end{array}$ & $\begin{array}{c}0.074 \\
(0.051)\end{array}$ & $\begin{array}{c}0.207^{*} \\
(0.108)\end{array}$ & $\begin{array}{l}-0.002 \\
(0.086)\end{array}$ \\
\hline $\begin{array}{l}\text { Treatment } \times \text { Ineligible } \times \ldots \\
\quad \ldots \text { Attendance Index }\end{array}$ & $\begin{array}{c}0.792 \\
(0.603)\end{array}$ & $\begin{array}{c}0.670 \\
(0.757)\end{array}$ & $\begin{array}{l}2.037^{* *} \\
(1.015)\end{array}$ & $\begin{array}{l}-0.017 \\
(0.355)\end{array}$ & $\begin{array}{c}0.771 \\
(0.467)\end{array}$ & $\begin{array}{l}-0.225 \\
(0.554)\end{array}$ & $\begin{array}{c}0.012 \\
(0.322)\end{array}$ & $\begin{array}{c}0.614 \\
(0.415)\end{array}$ & $\begin{array}{l}-0.668 \\
(0.605)\end{array}$ \\
\hline $\begin{array}{l}\text { Treatment } \times \ldots \\
\quad \ldots \text { Pro-poor Spending Index }\end{array}$ & $\begin{array}{l}-0.067 \\
(0.096)\end{array}$ & $\begin{array}{l}-0.216 \\
(0.173)\end{array}$ & $\begin{array}{c}0.009 \\
(0.131)\end{array}$ & $\begin{array}{l}-0.048 \\
(0.034)\end{array}$ & $\begin{array}{l}-0.149 \\
(0.095)\end{array}$ & $\begin{array}{l}-0.012 \\
(0.031)\end{array}$ & $\begin{array}{l}-0.005 \\
(0.014)\end{array}$ & $\begin{array}{l}-0.037 \\
(0.040)\end{array}$ & $\begin{array}{c}0.030 \\
(0.042)\end{array}$ \\
\hline $\begin{array}{l}\text { Treatment } \times \ldots \\
\quad \ldots \text { Attendance Index }\end{array}$ & $\begin{array}{l}-0.198 \\
(0.433)\end{array}$ & $\begin{array}{c}0.014 \\
(0.566)\end{array}$ & $\begin{array}{l}-0.704 \\
(0.626)\end{array}$ & $\begin{array}{l}-0.078 \\
(0.117)\end{array}$ & $\begin{array}{l}-0.424 \\
(0.283)\end{array}$ & $\begin{array}{c}0.051 \\
(0.200)\end{array}$ & $\begin{array}{l}-0.026 \\
(0.080)\end{array}$ & $\begin{array}{l}-0.173 \\
(0.148)\end{array}$ & $\begin{array}{l}-0.098 \\
(0.173)\end{array}$ \\
\hline Treatment $\times$ Ineligible & $\begin{array}{c}-0.424 \\
(0.420)\end{array}$ & $\begin{array}{l}-0.322 \\
(0.483)\end{array}$ & $\begin{array}{l}-1.627^{* *} \\
(0.695)\end{array}$ & $\begin{array}{c}0.172 \\
(0.245)\end{array}$ & $\begin{array}{l}-0.415 \\
(0.303)\end{array}$ & $\begin{array}{c}0.261 \\
(0.394)\end{array}$ & $\begin{array}{c}0.112 \\
(0.218)\end{array}$ & $\begin{array}{c}-0.324 \\
(0.246)\end{array}$ & $\begin{array}{c}0.620 \\
(0.448)\end{array}$ \\
\hline Treatment & $\begin{array}{c}0.206 \\
(0.302)\end{array}$ & $\begin{array}{c}0.092 \\
(0.375)\end{array}$ & $\begin{array}{c}0.712^{*} \\
(0.425)\end{array}$ & $\begin{array}{c}0.037 \\
(0.080)\end{array}$ & $\begin{array}{c}0.345 \\
(0.216)\end{array}$ & $\begin{array}{l}-0.045 \\
(0.122)\end{array}$ & $\begin{array}{c}0.020 \\
(0.060)\end{array}$ & $\begin{array}{c}0.159 \\
(0.124)\end{array}$ & $\begin{array}{c}0.049 \\
(0.126)\end{array}$ \\
\hline Nontreatment Interactions & Yes & Yes & Yes & Yes & Yes & Yes & Yes & Yes & Yes \\
\hline Strata (zone-party) FE & Yes & Yes & Yes & Yes & Yes & Yes & Yes & Yes & Yes \\
\hline Ineligible control mean & 0.000 & 0.000 & 0.000 & 0.000 & 0.000 & 0.000 & 0.000 & 0.000 & 0.000 \\
\hline Eligible control mean & 0.478 & 0.577 & 0.294 & 0.022 & 0.038 & 0.000 & 0.000 & 0.000 & 0.000 \\
\hline Observations & 240 & 116 & 112 & 240 & 116 & 112 & 240 & 115 & 114 \\
\hline
\end{tabular}

Heteroskedasticity-robust standard errors in parentheses. ${ }^{*} p<.10,{ }^{* *} p<.05,{ }^{* * *} p<.01$.

Councilor-level cross section estimated with OLS. "Attendance Index" is overall councilor attendance at MCD committees of which they are a member, 2007-10. "Pro-poor Spending Index" is the mean z-score of three log preference-weighted spending amounts (2007-11), analogous to the dependent variable in Table I, column 3, for the pre-publication period. 
Table V: Effect of newspaper report card publication, attendance, and spending on councilor-level electoral outcomes

\begin{tabular}{|c|c|c|c|c|c|c|c|c|c|c|}
\hline & \multicolumn{5}{|c|}{ Councilor's vote share (0 if didn't run) } & \multicolumn{5}{|c|}{ Councilor wins in any ward } \\
\hline & (1) & $(2)$ & (3) & $\begin{array}{l}(4) \\
\ldots \text { from high- } \\
\text { slum ward }\end{array}$ & $\begin{array}{l}\text { (5) } \\
\ldots \text { from low- } \\
\text { slum ward }\end{array}$ & (6) & $(7)$ & (8) & $\begin{array}{l}(9) \\
\ldots \text { from high- } \\
\text { slum ward }\end{array}$ & $\begin{array}{l}(10) \\
\ldots \text { from low- } \\
\text { slum ward }\end{array}$ \\
\hline $\begin{array}{l}\text { Treatment } \times \text { Ineligible } \times \ldots \\
\quad \ldots \text { Pro-poor Spending Index }\end{array}$ & & & $\begin{array}{l}0.096^{* *} \\
(0.047)\end{array}$ & $\begin{array}{l}0.213^{* *} \\
(0.085)\end{array}$ & $\begin{array}{c}0.032 \\
(0.065)\end{array}$ & & & $\begin{array}{l}0.230^{* *} \\
(0.117)\end{array}$ & $\begin{array}{l}0.494^{* * *} \\
(0.181)\end{array}$ & $\begin{array}{c}0.046 \\
(0.131)\end{array}$ \\
\hline $\begin{array}{l}\text { Treatment } \times \text { Ineligible } \times \ldots \\
\ldots \text { Attendance Index }\end{array}$ & & & $\begin{array}{c}0.314 \\
(0.233)\end{array}$ & $\begin{array}{c}0.223 \\
(0.305)\end{array}$ & $\begin{array}{l}1.096^{* * *} \\
(0.306)\end{array}$ & & & $\begin{array}{c}0.583 \\
(0.595)\end{array}$ & $\begin{array}{c}0.340 \\
(0.877)\end{array}$ & $\begin{array}{l}1.620^{* *} \\
(0.706)\end{array}$ \\
\hline $\begin{array}{l}\text { Treatment } \times \ldots \\
\quad \ldots \text { Pro-poor Spending Index }\end{array}$ & & & $\begin{array}{l}-0.046 \\
(0.038)\end{array}$ & $\begin{array}{c}-0.115^{*} \\
(0.069)\end{array}$ & $\begin{array}{c}0.013 \\
(0.058)\end{array}$ & & & $\begin{array}{l}-0.131 \\
(0.104)\end{array}$ & $\begin{array}{r}-0.296^{*} \\
(0.160)\end{array}$ & $\begin{array}{l}-0.027 \\
(0.115)\end{array}$ \\
\hline $\begin{array}{l}\text { Treatment } \times \ldots \\
\quad \ldots \text { Attendance Index }\end{array}$ & & & $\begin{array}{l}-0.022 \\
(0.165)\end{array}$ & $\begin{array}{c}0.160 \\
(0.255)\end{array}$ & $\begin{array}{l}-0.402^{*} \\
(0.203)\end{array}$ & & & $\begin{array}{c}0.021 \\
(0.479)\end{array}$ & $\begin{array}{c}0.290 \\
(0.777)\end{array}$ & $\begin{array}{l}-0.384 \\
(0.505)\end{array}$ \\
\hline Treatment $\times$ Ineligible & & $\begin{array}{c}0.024 \\
(0.047)\end{array}$ & $\begin{array}{l}-0.176 \\
(0.170)\end{array}$ & $\begin{array}{l}-0.098 \\
(0.209)\end{array}$ & $\begin{array}{l}-0.875^{* * *} \\
(0.206)\end{array}$ & & $\begin{array}{c}0.093 \\
(0.098)\end{array}$ & $\begin{array}{l}-0.266 \\
(0.414)\end{array}$ & $\begin{array}{l}-0.074 \\
(0.609)\end{array}$ & $\begin{array}{c}-1.226^{* *} \\
(0.483)\end{array}$ \\
\hline Treatment & $\begin{array}{c}0.047^{*} \\
(0.027)\end{array}$ & $\begin{array}{c}0.032 \\
(0.035)\end{array}$ & $\begin{array}{c}0.048 \\
(0.121)\end{array}$ & $\begin{array}{l}-0.066 \\
(0.180)\end{array}$ & $\begin{array}{c}0.364^{* *} \\
(0.138)\end{array}$ & $\begin{array}{c}0.029 \\
(0.057)\end{array}$ & $\begin{array}{c}-0.014 \\
(0.080)\end{array}$ & $\begin{array}{l}-0.033 \\
(0.336)\end{array}$ & $\begin{array}{l}-0.195 \\
(0.557)\end{array}$ & $\begin{array}{c}0.347 \\
(0.340)\end{array}$ \\
\hline Nontreatment Interactions & No & Yes & Yes & Yes & Yes & No & Yes & Yes & Yes & Yes \\
\hline Strata (zone-party) FE & Yes & Yes & Yes & Yes & Yes & Yes & Yes & Yes & Yes & Yes \\
\hline Ineligible control mean & 0.000 & 0.000 & 0.000 & 0.000 & 0.000 & 0.000 & 0.000 & 0.000 & 0.000 & 0.000 \\
\hline Eligible control mean & 0.171 & 0.171 & 0.171 & 0.204 & 0.114 & 0.304 & 0.304 & 0.304 & 0.346 & 0.176 \\
\hline Observations & 240 & 240 & 240 & 116 & 112 & 240 & 240 & 240 & 116 & 112 \\
\hline
\end{tabular}

Heteroskedasticity-robust standard errors in parentheses. ${ }^{*} p<.10,{ }^{* *} p<.05, * * * p<.01$.

Councilor-level cross section estimated with OLS. "Attendance Index" is overall councilor attendance at MCD committees of which they are a member, 2007-10. "Pro-poor Spending Index" is the mean z-score of three log preference-weighted spending amounts (2007-11), analogous to the dependent variable in Table I, column 3, for the pre-publication period. 
Table VI: Effect of newspaper report card publication, attendance, and spending on ward-level party electoral outcomes

\begin{tabular}{|c|c|c|c|c|c|c|c|c|c|c|}
\hline & \multicolumn{5}{|c|}{ Incumbent's party's vote share in same ward } & \multicolumn{5}{|c|}{ Incumbent's party wins in same ward } \\
\hline & $(1)$ & $(2)$ & $(3)$ & $\begin{array}{c}(4) \\
\ldots \text { in high- } \\
\text { slum ward }\end{array}$ & $\begin{array}{c}(5) \\
\ldots \text { in low- } \\
\text { slum ward }\end{array}$ & $(6)$ & $(7)$ & $(8)$ & $\begin{array}{c}\text { (9) } \\
\text {.. in high- } \\
\text { slum ward }\end{array}$ & $\begin{array}{l}\quad(10) \\
\ldots \text { in low- } \\
\text { slum ward }\end{array}$ \\
\hline $\begin{array}{l}\text { Treatment } \times \text { Ineligible } \times \ldots \\
\quad \ldots \text { Pro-poor Spending Index }\end{array}$ & & & $\begin{array}{l}0.095^{* * *} \\
(0.035)\end{array}$ & $\begin{array}{l}0.096^{* *} \\
(0.045)\end{array}$ & $\begin{array}{c}0.087 \\
(0.070)\end{array}$ & & & $\begin{array}{c}0.165 \\
(0.163)\end{array}$ & $\begin{array}{c}0.294 \\
(0.237)\end{array}$ & $\begin{array}{c}0.025 \\
(0.212)\end{array}$ \\
\hline $\begin{array}{l}\text { Treatment } \times \text { Ineligible } \times \ldots \\
\quad \ldots \text { Attendance Index }\end{array}$ & & & $\begin{array}{c}0.303 \\
(0.221)\end{array}$ & $\begin{array}{c}0.242 \\
(0.211)\end{array}$ & $\begin{array}{c}0.519 \\
(0.479)\end{array}$ & & & $\begin{array}{c}0.305 \\
(0.833)\end{array}$ & $\begin{array}{l}-0.401 \\
(1.239)\end{array}$ & $\begin{array}{c}2.229 \\
(1.344)\end{array}$ \\
\hline $\begin{array}{l}\text { Treatment } \times \ldots \\
\quad \ldots \text { Pro-poor Spending Index }\end{array}$ & & & $\begin{array}{l}-0.017 \\
(0.024)\end{array}$ & $\begin{array}{l}-0.070^{*} \\
(0.036)\end{array}$ & $\begin{array}{c}0.038 \\
(0.052)\end{array}$ & & & $\begin{array}{l}-0.144 \\
(0.096)\end{array}$ & $\begin{array}{l}-0.435^{* * *} \\
(0.158)\end{array}$ & $\begin{array}{c}0.102 \\
(0.151)\end{array}$ \\
\hline $\begin{array}{l}\text { Treatment } \times \ldots \\
\quad \ldots \text { Attendance Index }\end{array}$ & & & $\begin{array}{c}0.063 \\
(0.112)\end{array}$ & $\begin{array}{c}0.134 \\
(0.163)\end{array}$ & $\begin{array}{l}-0.106 \\
(0.218)\end{array}$ & & & $\begin{array}{l}-0.293 \\
(0.510)\end{array}$ & $\begin{array}{c}0.010 \\
(0.834)\end{array}$ & $\begin{array}{l}-0.988 \\
(0.804)\end{array}$ \\
\hline Treatment $\times$ Ineligible & & $\begin{array}{l}-0.000 \\
(0.041)\end{array}$ & $\begin{array}{l}-0.181 \\
(0.152)\end{array}$ & $\begin{array}{l}-0.141 \\
(0.147)\end{array}$ & $\begin{array}{l}-0.415 \\
(0.336)\end{array}$ & & $\begin{array}{l}-0.033 \\
(0.149)\end{array}$ & $\begin{array}{l}-0.248 \\
(0.562)\end{array}$ & $\begin{array}{c}0.261 \\
(0.833)\end{array}$ & $\begin{array}{c}-1.914^{* *} \\
(0.939)\end{array}$ \\
\hline Treatment & $\begin{array}{c}-0.002 \\
(0.018)\end{array}$ & $\begin{array}{c}-0.001 \\
(0.022)\end{array}$ & $\begin{array}{c}-0.047 \\
(0.080)\end{array}$ & $\begin{array}{c}-0.096 \\
(0.120)\end{array}$ & $\begin{array}{c}0.085 \\
(0.153)\end{array}$ & $\begin{array}{c}-0.026 \\
(0.069)\end{array}$ & $\begin{array}{c}-0.012 \\
(0.088)\end{array}$ & $\begin{array}{c}0.178 \\
(0.344)\end{array}$ & $\begin{array}{c}-0.007 \\
(0.594)\end{array}$ & $\begin{array}{c}0.739 \\
(0.528)\end{array}$ \\
\hline Nontreatment Interactions & No & Yes & Yes & Yes & Yes & No & Yes & Yes & Yes & Yes \\
\hline Strata (zone-party) FE & Yes & Yes & Yes & Yes & Yes & Yes & Yes & Yes & Yes & Yes \\
\hline Ineligible control mean & 0.408 & 0.408 & 0.408 & 0.381 & 0.449 & 0.615 & 0.615 & 0.615 & 0.500 & 0.769 \\
\hline Eligible control mean & 0.347 & 0.347 & 0.347 & 0.371 & 0.331 & 0.500 & 0.500 & 0.500 & 0.577 & 0.353 \\
\hline Observations & 240 & 240 & 240 & 116 & 112 & 240 & 240 & 240 & 116 & 112 \\
\hline
\end{tabular}

Heteroskedasticity-robust standard errors in parentheses. ${ }^{*} p<.10,{ }^{* *} p<.05,{ }^{* * *} p<.01$.

Ward-level cross section estimated with OLS. "Attendance Index" is overall attendance at MCD committees of which they are a member, 2007-10. "Pro-poor Spending Index" is the mean z-score of three log preference-weighted spending amounts (2007-11), analogous to the dependent variable in Table I, column 3, for the pre-publication period. 
Table VII: Effect of newspaper report card spending yardstick on councilor-level electoral outcomes among treated councilors

\begin{tabular}{|c|c|c|c|c|c|}
\hline & $\begin{array}{l}\text { Councilor runs } \\
\text { in any ward }\end{array}$ & $\begin{array}{l}\text { Councilor runs } \\
\text { in other ward }\end{array}$ & $\begin{array}{l}\text { Councilor runs } \\
\text { in other ward } \\
\text { controlled by party }\end{array}$ & $\begin{array}{c}\text { Councilor's } \\
\text { vote share } \\
\text { (0 if didn't run) }\end{array}$ & $\begin{array}{l}\text { Councilor wins } \\
\text { in any ward }\end{array}$ \\
\hline & (1) & $(2)$ & (3) & (4) & $(5)$ \\
\hline \multirow[t]{2}{*}{ Ineligible $\times$ Rank } & $-0.319^{*}$ & $-0.146^{*}$ & -0.074 & $-0.145^{* *}$ & -0.173 \\
\hline & $(0.163)$ & $(0.079)$ & $(0.057)$ & $(0.056)$ & $(0.119)$ \\
\hline \multirow{2}{*}{ Publication Date $\times$ Rank } & 0.154 & 0.053 & 0.064 & 0.165 & 0.276 \\
\hline & $(0.249)$ & $(0.082)$ & $(0.079)$ & $(0.105)$ & $(0.218)$ \\
\hline \multirow[t]{2}{*}{ Rank } & -0.011 & -0.015 & -0.013 & -0.029 & -0.084 \\
\hline & $(0.112)$ & $(0.024)$ & $(0.024)$ & $(0.051)$ & $(0.100)$ \\
\hline Pro-Poor Spending controls & Yes & Yes & Yes & Yes & Yes \\
\hline Ineligible FE & Yes & Yes & Yes & Yes & Yes \\
\hline Pub Date control & Yes & Yes & Yes & Yes & Yes \\
\hline Strata (zone-party) FE & Yes & Yes & Yes & Yes & Yes \\
\hline Ineligible treated mean & 0.115 & 0.115 & 0.077 & 0.022 & 0.038 \\
\hline Eligible treated mean & 0.592 & 0.010 & 0.010 & 0.222 & 0.337 \\
\hline Observations & 124 & 124 & 124 & 124 & 124 \\
\hline
\end{tabular}

Heteroskedasticity-robust standard errors in parentheses. ${ }^{*} p<.10,{ }^{* *} p<.05,{ }^{* * *} p<.01$.

Councilor-level cross section estimated with OLS. "Rank" is the rank of the councilor's mean z-score of three log preference-weighted spending amounts among the four councilors whose report cards appeared in the same newspaper. (Highest $=0$; lowest $=3$.) 'Publication Date' is scaled between 0 (first issue published) and 1 (last issue published). 'Pro-Poor Spending controls' are 'Pro-Poor Spending Index', 'Ineligible $\times$ Pro-Poor Spending Index', and 'Publication Date $\times$ Pro-Poor Spending Index'. 


\section{Appendix: Tables and Figures}

Table A.I: Baseline check of newspaper report card treatment with councilor spending and constituent preferences

\begin{tabular}{|c|c|c|c|c|c|c|c|}
\hline & $\begin{array}{c}\text { (1) } \\
\text { Roads and } \\
\text { lanes }\end{array}$ & $\begin{array}{c}(2) \\
\text { Sewage } \\
\text { and } \\
\text { drainage }\end{array}$ & $\begin{array}{c}\text { (3) } \\
\text { Parks and } \\
\text { greenery }\end{array}$ & $\begin{array}{c}(4) \\
\text { Education } \\
\text { and } \\
\text { schools }\end{array}$ & $\begin{array}{l}\quad(5) \\
\text { Garbage } \\
\text { removal }\end{array}$ & $\begin{array}{c}(6) \\
\text { Other } \\
\text { areas }\end{array}$ & (7) \\
\hline \multicolumn{8}{|c|}{ Panel: Spending (all wards) } \\
\hline Treatment & $\begin{array}{c}-0.004 \\
(0.022)\end{array}$ & $\begin{array}{c}-0.005 \\
(0.016)\end{array}$ & $\begin{array}{c}0.007 \\
(0.008)\end{array}$ & $\begin{array}{c}0.004 \\
(0.007)\end{array}$ & $\begin{array}{c}0.001 \\
(0.002)\end{array}$ & $\begin{array}{c}-0.003 \\
(0.013)\end{array}$ & $\begin{array}{l}0.000 \\
-\end{array}$ \\
\hline Strata (zone-party) FE & Yes & Yes & Yes & Yes & Yes & Yes & Yes \\
\hline Control mean & 0.552 & 0.178 & 0.060 & 0.024 & 0.008 & 0.178 & 1.000 \\
\hline Control s.d. & 0.183 & 0.130 & 0.067 & 0.034 & 0.013 & 0.114 & 0.000 \\
\hline Observations & 240 & 240 & 240 & 240 & 240 & 240 & 240 \\
\hline \multicolumn{8}{|c|}{ Panel: Spending (slum survey wards) } \\
\hline Treatment & $\begin{array}{c}-0.017 \\
(0.037)\end{array}$ & $\begin{array}{c}0.018 \\
(0.028)\end{array}$ & $\begin{array}{c}-0.003 \\
(0.015)\end{array}$ & $\begin{array}{c}0.001 \\
(0.005)\end{array}$ & $\begin{array}{c}-0.001 \\
(0.003)\end{array}$ & $\begin{array}{c}0.002 \\
(0.019)\end{array}$ & $\begin{array}{l}0.000 \\
-\end{array}$ \\
\hline Strata (zone-party) FE & Yes & Yes & Yes & Yes & Yes & Yes & Yes \\
\hline Control mean & 0.542 & 0.187 & 0.073 & 0.019 & 0.008 & 0.171 & 1.000 \\
\hline Control s.d. & 0.194 & 0.142 & 0.070 & 0.023 & 0.012 & 0.094 & 0.000 \\
\hline Observations & 106 & 106 & 106 & 106 & 106 & 106 & 106 \\
\hline \multicolumn{8}{|l|}{ Panel: Slum HH preference } \\
\hline Report card & $\begin{array}{c}0.005 \\
(0.011)\end{array}$ & $\begin{array}{c}-0.014 \\
(0.040)\end{array}$ & $\begin{array}{c}0.001 \\
(0.003)\end{array}$ & $\begin{array}{c}-0.006 \\
(0.016)\end{array}$ & $\begin{array}{c}0.026 \\
(0.045)\end{array}$ & $\begin{array}{c}-0.079 \\
(0.073)\end{array}$ & $\begin{array}{c}-0.067 \\
(0.099)\end{array}$ \\
\hline Strata (zone-party) FE & Yes & Yes & Yes & Yes & Yes & Yes & Yes \\
\hline Control mean & 0.020 & 0.688 & 0.002 & 0.046 & 0.513 & 1.581 & 2.851 \\
\hline Control s.d. & 0.043 & 0.180 & 0.007 & 0.063 & 0.195 & 0.389 & 0.411 \\
\hline Observations & 106 & 106 & 106 & 106 & 106 & 106 & 106 \\
\hline
\end{tabular}

Heteroskedasticity-robust standard errors in parentheses. ${ }^{*} p<.10,{ }^{* *} p<.05,{ }^{* * *} p<.01$.

Ward-level OLS regression. "Spending (all wards)" is the fraction of total MCD councilor spending (calculated over pre-treatment period) booked for each area. "Spending (slum survey wards)" is an equivalent measure restricted to wards in which we surveyed slum households. Spending is categorized by lexical heuristic. "Slum HH preference" is the ward-mean of households in slum areas who specify each area in response to the question, "In which of the following areas have you personally faced problems in the last year?" (The total is the mean number of areas named by households.) Household responses are weighted within wards to correct for differential coverage of surveys between slums. 
Table A.II: Baseline check of newspaper report card treatment with councilor electoral outcomes

\begin{tabular}{|c|c|c|c|c|c|c|}
\hline & \multicolumn{5}{|c|}{2007 Election } & \multirow{2}{*}{$\begin{array}{c}2012 \text { Election } \\
(6) \\
\text { Eligible } \\
\text { for reelection }\end{array}$} \\
\hline & $\begin{array}{c}\quad(1) \\
\text { Log regis- } \\
\text { tered voters }\end{array}$ & $\begin{array}{c}(2) \\
\text { Log } \\
\text { turnout }\end{array}$ & $\begin{array}{l}\quad(3) \\
\text { Seat reserved } \\
\text { for minority }\end{array}$ & $\begin{array}{c}(4) \\
\text { Number of } \\
\text { candidates }\end{array}$ & $\begin{array}{c}(5) \\
\text { Winner's } \\
\text { vote share }\end{array}$ & \\
\hline Treatment $\times$ Ineligible $(2012)$ & $\begin{array}{c}-0.051 \\
(0.047)\end{array}$ & $\begin{array}{c}-0.009 \\
(0.057)\end{array}$ & $\begin{array}{c}0.072 \\
(0.128)\end{array}$ & $\begin{array}{c}-0.214 \\
(1.162)\end{array}$ & $\begin{array}{c}-0.032 \\
(0.041)\end{array}$ & \\
\hline Treatment & $\begin{array}{c}-0.004 \\
(0.032)\end{array}$ & $\begin{array}{c}-0.022 \\
(0.038)\end{array}$ & $\begin{array}{c}-0.060 \\
(0.086)\end{array}$ & $\begin{array}{c}0.113 \\
(0.767)\end{array}$ & $\begin{array}{c}0.056^{*} \\
(0.034)\end{array}$ & $\begin{array}{c}0.040 \\
(0.067)\end{array}$ \\
\hline Ineligible (2012) & $\begin{array}{c}0.002 \\
(0.038)\end{array}$ & $\begin{array}{l}-0.017 \\
(0.044)\end{array}$ & $\begin{array}{l}-0.438^{* * *} \\
(0.106)\end{array}$ & $\begin{array}{c}0.405 \\
(0.948)\end{array}$ & $\begin{array}{c}0.013 \\
(0.022)\end{array}$ & \\
\hline Control mean & 10.500 & 9.643 & 0.472 & 9.472 & 0.395 & 0.639 \\
\hline Control s.d. & 0.168 & 0.198 & 0.503 & 4.121 & 0.097 & 0.484 \\
\hline Observations & 240 & 240 & 240 & 240 & 240 & 240 \\
\hline
\end{tabular}

Heteroskedasticity-robust standard errors in parentheses. ${ }^{*} p<.10,{ }^{* *} p<.05,{ }^{* * *} p<.01$. 
Table A.III: Characteristics of wards in 2012 MCD elections by slum fraction

\begin{tabular}{|c|c|c|c|}
\hline Variable & $\begin{array}{c}(1) \\
\text { Low slum } \\
\text { Mean/SE }\end{array}$ & $\begin{array}{c}(2) \\
\text { High slum } \\
\text { Mean/SE }\end{array}$ & $\begin{array}{c}t \text {-test } \\
p \text {-value } \\
(1)-(2)\end{array}$ \\
\hline Incumbent eligible & $\begin{array}{c}.65 \\
(.045)\end{array}$ & $\begin{array}{c}.68 \\
(.043)\end{array}$ & .64 \\
\hline Incumbent's pro-poor spending index & $\begin{array}{l}-.21 \\
(.12)\end{array}$ & $\begin{array}{l}-.016 \\
(.089)\end{array}$ & .20 \\
\hline Incumbent's attendance index & $\begin{array}{c}.65 \\
(.017)\end{array}$ & $\begin{array}{c}.68 \\
(.017)\end{array}$ & .24 \\
\hline Incumbent runs in any ward & $\begin{array}{c}.37 \\
(.046)\end{array}$ & $\begin{array}{c}.42 \\
(.046)\end{array}$ & .39 \\
\hline Incumbent runs in other ward & $\begin{array}{c}.027 \\
(.015)\end{array}$ & $\begin{array}{c}.052 \\
(.021)\end{array}$ & .33 \\
\hline Incumbent wins in same ward if eligible & $\begin{array}{c}.21 \\
(.038)\end{array}$ & $\begin{array}{c}.19 \\
(.037)\end{array}$ & .77 \\
\hline Incumbent's vote share in same ward & $\begin{array}{c}.13 \\
(.019)\end{array}$ & $\begin{array}{c}.13 \\
(.018)\end{array}$ & .88 \\
\hline Incumbent's party wins in same ward & $\begin{array}{c}.50 \\
(.047)\end{array}$ & $\begin{array}{c}.54 \\
(.046)\end{array}$ & .52 \\
\hline Incumbent's party's vote share in same ward & $\begin{array}{c}.37 \\
(.016)\end{array}$ & $\begin{array}{c}.37 \\
(.012)\end{array}$ & .86 \\
\hline Voter turnout & $\begin{array}{c}.54 \\
(.0062)\end{array}$ & $\begin{array}{c}.54 \\
(.0049)\end{array}$ & .59 \\
\hline Voter registration & $\begin{array}{l}41806 \\
(1058)\end{array}$ & $\begin{array}{l}41115 \\
(830)\end{array}$ & .61 \\
\hline $\mathrm{N}$ & 112 & 116 & \\
\hline
\end{tabular}

Heteroskedasticity-robust standard errors in parentheses. ${ }^{*} p<.10,{ }^{* *} p<.05,{ }^{* * *} p<.01$. 
Table A.IV: Effect of any newspaper report card treatment on MCD councilor spending according to slum preferences

\begin{tabular}{|c|c|c|c|c|c|c|}
\hline & \multicolumn{2}{|c|}{$\begin{array}{l}\text { Log total } \\
(2010-12)\end{array}$} & \multicolumn{2}{|c|}{$\begin{array}{l}\text { Pro-poor spending in- } \\
\operatorname{dex}(2010-2012)\end{array}$} & \multicolumn{2}{|c|}{$\begin{array}{l}\text { Attendance } \\
(2010-12)\end{array}$} \\
\hline & (1) & $(2)$ & (3) & $(4)$ & (5) & (6) \\
\hline T1: 2012 report $($ ITT) $\times$ High slum & & $\begin{array}{l}-0.085 \\
(0.102)\end{array}$ & & $\begin{array}{c}0.493 \\
(0.369)\end{array}$ & & $\begin{array}{c}0.091 \\
(0.234)\end{array}$ \\
\hline T2: 2010/12 reports $($ ITT $) \times$ High slum & & $\begin{array}{l}-0.023 \\
(0.082)\end{array}$ & & $\begin{array}{l}0.684^{* *} \\
(0.300)\end{array}$ & & $\begin{array}{l}0.521^{* *} \\
(0.221)\end{array}$ \\
\hline T1: 2012 report (ITT) & $\begin{array}{c}0.072 \\
(0.054)\end{array}$ & $\begin{array}{r}0.131^{*} \\
(0.077)\end{array}$ & $\begin{array}{c}0.018 \\
(0.162)\end{array}$ & $\begin{array}{l}-0.227 \\
(0.246)\end{array}$ & $\begin{array}{c}0.037 \\
(0.115)\end{array}$ & $\begin{array}{l}-0.094 \\
(0.148)\end{array}$ \\
\hline T2: 2010/12 reports (ITT) & $\begin{array}{l}-0.031 \\
(0.042)\end{array}$ & $\begin{array}{c}0.004 \\
(0.062)\end{array}$ & $\begin{array}{l}-0.024 \\
(0.143)\end{array}$ & $\begin{array}{l}-0.356^{*} \\
(0.208)\end{array}$ & $\begin{array}{c}0.026 \\
(0.112)\end{array}$ & $\begin{array}{r}-0.304^{*} \\
(0.168)\end{array}$ \\
\hline High slum & & $\begin{array}{l}-0.004 \\
(0.066)\end{array}$ & & $\begin{array}{l}-0.234 \\
(0.251)\end{array}$ & & $\begin{array}{l}-0.246 \\
(0.168)\end{array}$ \\
\hline Pre-treat outcome control & Yes & Yes & Yes & Yes & Yes & Yes \\
\hline Strata (zone-party) FE & Yes & Yes & Yes & Yes & Yes & Yes \\
\hline $\begin{array}{l}p \text {-value: } T 1 \times H i g h+T 1=T 2 \times H i g h+T 2 \\
p \text {-value: } T 1=T 2\end{array}$ & 0.042 & $\begin{array}{l}0.330 \\
0.097\end{array}$ & 0.772 & $\begin{array}{l}0.794 \\
0.510\end{array}$ & 0.923 & $\begin{array}{l}0.141 \\
0.226\end{array}$ \\
\hline Observations & 240 & 227 & 240 & 227 & 240 & 227 \\
\hline
\end{tabular}

Heteroskedasticity-robust standard errors in parentheses. ${ }^{*} p<.10,{ }^{* *} p<.05,{ }^{* * *} p<.01$.

Ward-level OLS regression. Pro-poor spending index components are each log spending on issues, with each issue weighted by the fraction of slum households in the city reporting that (1) it is the most problematic in the area, (2) it is a problem for them, and (3) it is a problem for the community. Attendance index components are councilor attendance at (1) the general assembly and (2) councilor committee meetings. Spending is categorized by lexical heuristic. 
Table A.V: Effect of any newspaper report card treatment on spending and attendance index components

\begin{tabular}{|c|c|c|c|c|c|c|c|c|c|}
\hline & \multicolumn{2}{|c|}{$\begin{array}{l}\text { Pro-poor spending in- } \\
\text { dex }(2010-2012)\end{array}$} & \multicolumn{3}{|c|}{ Spending index components } & \multicolumn{2}{|c|}{$\begin{array}{l}\text { Attendance } \\
(2010-12)\end{array}$} & \multicolumn{2}{|c|}{$\begin{array}{l}\text { Attendance index com- } \\
\text { ponents }\end{array}$} \\
\hline & $(1)$ & $(2)$ & $\begin{array}{r}(3) \\
\text { Biggest } \\
\text { problem }\end{array}$ & $\begin{array}{l}\quad(4) \\
\text { Problem for } \\
\text { individual }\end{array}$ & $\begin{array}{l}\quad(5) \\
\text { Problem for } \\
\text { community }\end{array}$ & (6) & (7) & $\begin{array}{c}\text { (8) } \\
\text { Assembly }\end{array}$ & $\begin{array}{c}\text { (9) } \\
\text { Committees }\end{array}$ \\
\hline Treatment $\times$ High slum & & $\begin{array}{l}0.617^{* *} \\
(0.288)\end{array}$ & $\begin{array}{c}1.425^{* *} \\
(0.631)\end{array}$ & $\begin{array}{l}1.263^{* *} \\
(0.607)\end{array}$ & $\begin{array}{l}1.287^{* *} \\
(0.617)\end{array}$ & & $\begin{array}{r}0.372^{*} \\
(0.196)\end{array}$ & $\begin{array}{l}0.069^{* *} \\
(0.033)\end{array}$ & $\begin{array}{c}0.044 \\
(0.040)\end{array}$ \\
\hline Treatment & $\begin{array}{l}-0.010 \\
(0.133)\end{array}$ & $\begin{array}{l}-0.309 \\
(0.201)\end{array}$ & $\begin{array}{l}-0.686 \\
(0.438)\end{array}$ & $\begin{array}{l}-0.650 \\
(0.426)\end{array}$ & $\begin{array}{l}-0.657 \\
(0.433)\end{array}$ & $\begin{array}{c}0.030 \\
(0.100)\end{array}$ & $\begin{array}{l}-0.227 \\
(0.138)\end{array}$ & $\begin{array}{l}-0.045^{* *} \\
(0.023)\end{array}$ & $\begin{array}{l}-0.019 \\
(0.030)\end{array}$ \\
\hline High slum & & $\begin{array}{l}-0.230 \\
(0.250)\end{array}$ & $\begin{array}{c}-0.531 \\
(0.548)\end{array}$ & $\begin{array}{c}-0.474 \\
(0.528)\end{array}$ & $\begin{array}{l}-0.478 \\
(0.536)\end{array}$ & & $\begin{array}{c}-0.238 \\
(0.166)\end{array}$ & $\begin{array}{c}-0.043 \\
(0.028)\end{array}$ & $\begin{array}{c}-0.023 \\
(0.033)\end{array}$ \\
\hline Pre-treat outcome control & Yes & Yes & Yes & Yes & Yes & Yes & Yes & Yes & Yes \\
\hline Strata (zone-party) FE & Yes & Yes & Yes & Yes & Yes & Yes & Yes & Yes & Yes \\
\hline Pre-treat control mean & -0.000 & 0.019 & 3.196 & 6.480 & 6.403 & 0.000 & -0.004 & 0.816 & 0.651 \\
\hline Pre-treat control s.d. & 1.000 & 0.923 & 2.034 & 1.941 & 1.973 & 0.893 & 0.912 & 0.127 & 0.190 \\
\hline$p$-value: $T \times H i g h+T+H i g h=0$ & & 0.722 & 0.661 & 0.762 & 0.745 & & 0.453 & 0.350 & 0.919 \\
\hline$p$-value: $T \times H i g h+T+H i g h=T$ & & 0.012 & 0.009 & 0.015 & 0.015 & & 0.248 & 0.183 & 0.395 \\
\hline$p$-value: $T \times H i g h+T+H i g h=H i g h$ & & 0.123 & 0.091 & 0.144 & 0.140 & & 0.301 & 0.324 & 0.357 \\
\hline Observations & 240 & 227 & 227 & 227 & 227 & 240 & 227 & 224 & 227 \\
\hline
\end{tabular}

Heteroskedasticity-robust standard errors in parentheses. ${ }^{*} p<.10,{ }^{* *} p<.05,{ }^{* * *} p<.01$

Ward-level OLS regression. Pro-poor spending index components are each log spending on issues, with each issue weighted by the fraction of slum households in the city reporting that (1) it is the most problematic in the area, (2) it is a problem for them, and (3) it is a problem for the community. Attendance index components are councilor attendance at (1) the general assembly and (2) councilor committee meetings. "Treatment" indicates observations of a ward in which a report card on the performance of the MCD councilor was published in a newspaper during the 2012 pre-election period (T1 or T2, ITT). 
Table A.VI: Effect of any newspaper report card treatment on MCD councilor spending on selected spending categories

\begin{tabular}{|c|c|c|c|c|c|c|}
\hline & \multicolumn{6}{|c|}{ Log spending... } \\
\hline & (1) & $(2)$ & $(3)$ & $(4)$ & $(5)$ & $(6)$ \\
\hline & ...total & ... on drains & ... on garbage/malba & ... on schools & $\ldots$ on roads & ... on parks \\
\hline \multirow[t]{2}{*}{ Treatment $\times$ High slum } & -0.049 & 0.683 & 0.129 & -0.556 & -0.016 & -0.131 \\
\hline & $(0.074)$ & $(0.439)$ & $(0.151)$ & $(0.404)$ & $(0.146)$ & $(0.460)$ \\
\hline \multirow[t]{2}{*}{ Treatment } & 0.050 & -0.325 & -0.158 & 0.115 & -0.015 & 0.516 \\
\hline & $(0.057)$ & $(0.311)$ & $(0.105)$ & $(0.291)$ & $(0.106)$ & $(0.348)$ \\
\hline \multirow[t]{2}{*}{ High slum } & -0.002 & -0.117 & -0.034 & 0.386 & -0.045 & 0.123 \\
\hline & $(0.065)$ & $(0.380)$ & $(0.129)$ & $(0.343)$ & $(0.126)$ & $(0.398)$ \\
\hline Pre-treat spending control & Yes & Yes & Yes & Yes & Yes & Yes \\
\hline Strata (zone-party) FE & Yes & Yes & Yes & Yes & Yes & Yes \\
\hline Control mean & 4.555 & 1.847 & -0.179 & -0.418 & 3.865 & 0.710 \\
\hline Control s.d. & 0.248 & 1.539 & 0.567 & 1.410 & 0.500 & 1.655 \\
\hline$p$-value: $T \times H i g h+T+H i g h=0$ & 0.994 & 0.462 & 0.531 & 0.850 & 0.488 & 0.150 \\
\hline$p$-value: $T \times H i g h+T+H i g h=T$ & 0.254 & 0.018 & 0.216 & 0.468 & 0.488 & 0.975 \\
\hline$p$-value: $T \times H i g h+T+H i g h=H i g h$ & 0.977 & 0.235 & 0.774 & 0.108 & 0.755 & 0.207 \\
\hline Observations & 227 & 227 & 227 & 227 & 227 & 227 \\
\hline
\end{tabular}

Heteroskedasticity-robust standard errors in parentheses. ${ }^{*} p<.10,{ }^{* *} p<.05,{ }^{* * *} p<.01$.

Ward-level OLS regression. "Treatment" indicates observations of a ward in which a report card on the performance of the MCD councilor was published in a newspaper during the 2012 pre-election period (T1 or T2, ITT). Amount of spending is in lakh rupees. Spending is categorized by lexical heuristic. 
Table A.VII: Effect of any newspaper report card treatment on MCD councilor spending according to slum preferences

\begin{tabular}{|c|c|c|c|c|c|c|}
\hline & \multirow{2}{*}{$\begin{array}{l}\text { Log total } \\
(2010-12) \\
(1)\end{array}$} & \multirow{2}{*}{$\begin{array}{l}\text { spending } \\
(2)\end{array}$} & \multicolumn{2}{|c|}{$\begin{array}{l}\text { Pro-poor spending in- } \\
\operatorname{dex}(2010-2012)\end{array}$} & \multirow{2}{*}{$\begin{array}{l}\text { Attendance } \\
(2010-12) \\
(5)\end{array}$} & \multirow[t]{2}{*}{ index } \\
\hline & & & (3) & (4) & & \\
\hline Treatment $\times$ Survey ward & & $\begin{array}{c}-0.006 \\
(0.080)\end{array}$ & & $\begin{array}{c}0.529^{*} \\
(0.281)\end{array}$ & & $\begin{array}{c}0.025 \\
(0.211)\end{array}$ \\
\hline Treatment & $\begin{array}{c}0.005 \\
(0.040)\end{array}$ & $\begin{array}{c}0.006 \\
(0.063)\end{array}$ & $\begin{array}{l}-0.010 \\
(0.133)\end{array}$ & $\begin{array}{l}-0.234 \\
(0.194)\end{array}$ & $\begin{array}{c}0.030 \\
(0.100)\end{array}$ & $\begin{array}{c}0.025 \\
(0.144)\end{array}$ \\
\hline Survey ward & & $\begin{array}{l}-0.008 \\
(0.068)\end{array}$ & & $\begin{array}{l}-0.084 \\
(0.240)\end{array}$ & & $\begin{array}{c}0.039 \\
(0.170)\end{array}$ \\
\hline Pre-treat outcome control & Yes & Yes & Yes & Yes & Yes & Yes \\
\hline Strata (zone-party) FE & Yes & Yes & Yes & Yes & Yes & Yes \\
\hline Post-treat control mean & 4.552 & 4.552 & -1.854 & -1.854 & -0.394 & -0.394 \\
\hline Post-treat control s.d. & 0.243 & 0.243 & 1.053 & 1.053 & 1.162 & 1.162 \\
\hline$p$-value: $T \times S v y+T+S v y=0$ & & 0.904 & & 0.311 & & 0.557 \\
\hline$p$-value: $T \times S v y+T+S v y=T$ & & 0.742 & & 0.003 & & 0.587 \\
\hline$p$-value: $T \times S v y+T+S v y=S v y$ & & 0.999 & & 0.130 & & 0.734 \\
\hline Observations & 240 & 240 & 240 & 240 & 240 & 240 \\
\hline
\end{tabular}

Heteroskedasticity-robust standard errors in parentheses. ${ }^{*} p<.10,{ }^{* *} p<.05,{ }^{* * *} p<.01$.

Ward-level OLS regression. Pro-poor spending index components are each log spending on issues, with each issue weighted by the fraction of slum households in the city reporting that (1) it is the most problematic in the area, (2) it is a problem for them, and (3) it is a problem for the community. Attendance index components are councilor attendance at (1) the general assembly and (2) councilor committee meetings. "Treatment" indicates observations of a ward in which a report card on the performance of the MCD councilor was published in a newspaper during the 2012 pre-election period (T1 or T2, ITT). Spending is categorized by lexical heuristic. 
Table A.VIII: Effect of State of Sanitation Information on drainage management

\begin{tabular}{|c|c|c|c|}
\hline & $\begin{array}{c}(1) \\
\text { Total } \\
\text { drains }\end{array}$ & $\begin{array}{c}(2) \\
\text { Drains with } \\
\text { proper } \\
\text { disposing }(\%)\end{array}$ & $\begin{array}{c}(3) \\
\text { Drains } \\
\text { clogged (\%) }\end{array}$ \\
\hline SSI treatment & $\begin{array}{l}-0.006 \\
(0.089)\end{array}$ & $\begin{array}{l}-0.087 \\
(0.052)\end{array}$ & $\begin{array}{c}-0.048 \\
(0.133)\end{array}$ \\
\hline Control mean & 1.200 & 0.136 & 0.500 \\
\hline Observations & 132 & 132 & 132 \\
\hline
\end{tabular}

Standard errors clustered by ward in parentheses. $* p<.10$, ** $p<.05, * * * p<.01$.

Slum-level OLS regression. "SSI treatment" indicates observations in a slum of which the MCD councilor received State of Sanitation Information (ITT). "Total drains" is the number of drains in the slum. "Drains with proper disposing (\%)" is the fraction of drains from which extracted garbage was taken to a dhalao or a landfill, rather than left by the drain or burned. "Drains clogged (\%)" is the fraction of drains which are so clogged with trash at any point that the water is not visible. 
Table A.IX: Effect of newspaper report card publication by treatment arm on councilor-level electoral outcomes

\begin{tabular}{|c|c|c|c|c|c|}
\hline & $\begin{array}{l}\text { Councilor runs } \\
\text { in any ward }\end{array}$ & $\begin{array}{l}\text { Councilor runs } \\
\text { in other ward }\end{array}$ & $\begin{array}{l}\text { Councilor runs } \\
\text { in other ward } \\
\text { controlled by party }\end{array}$ & $\begin{array}{c}\text { Councilor's } \\
\text { vote share } \\
\text { (0 if didn't run) }\end{array}$ & $\begin{array}{l}\text { Councilor wins } \\
\text { in any ward }\end{array}$ \\
\hline & $(1)$ & $(2)$ & $(3)$ & $(4)$ & $(5)$ \\
\hline \multirow[t]{2}{*}{ T1: 2012 report $($ ITT $) \times$ Ineligible } & 0.186 & $0.144^{*}$ & 0.097 & 0.008 & 0.030 \\
\hline & $(0.151)$ & $(0.086)$ & $(0.073)$ & $(0.059)$ & $(0.128)$ \\
\hline \multirow[t]{2}{*}{ T2: 2010/12 reports $(\mathrm{ITT}) \times$ Ineligible } & 0.043 & $0.166^{* *}$ & $0.129 * *$ & 0.032 & 0.121 \\
\hline & $(0.128)$ & $(0.070)$ & $(0.064)$ & $(0.055)$ & $(0.111)$ \\
\hline \multirow[t]{2}{*}{ T1: 2012 report (ITT) } & 0.013 & -0.017 & 0.003 & 0.042 & 0.046 \\
\hline & $(0.112)$ & $(0.019)$ & $(0.013)$ & $(0.048)$ & $(0.104)$ \\
\hline \multirow[t]{2}{*}{ T2: 2010/12 reports (ITT) } & 0.096 & -0.009 & 0.009 & 0.028 & -0.040 \\
\hline & $(0.091)$ & $(0.021)$ & $(0.016)$ & $(0.037)$ & $(0.085)$ \\
\hline \multirow[t]{2}{*}{ Ineligible } & $-0.473^{* * *}$ & -0.027 & -0.009 & $-0.175^{* * *}$ & $-0.308^{* * *}$ \\
\hline & $(0.080)$ & $(0.022)$ & $(0.016)$ & $(0.033)$ & $(0.076)$ \\
\hline Strata (zone-party) FE & Yes & Yes & Yes & Yes & Yes \\
\hline Ineligible control mean & 0.000 & 0.000 & 0.000 & 0.000 & 0.000 \\
\hline Eligible control mean & 0.478 & 0.022 & 0.000 & 0.171 & 0.304 \\
\hline Observations & 240 & 240 & 240 & 240 & 240 \\
\hline
\end{tabular}

Heteroskedasticity-robust standard errors in parentheses. ${ }^{*} p<.10,{ }^{* *} p<.05,{ }^{* * *} p<.01$.

Councilor-level cross section estimated with OLS. 
Table A.X: Effect of newspaper report card publication, attendance, and spending by treatment arm on councilor-level electoral outcomes

\begin{tabular}{|c|c|c|c|c|c|c|c|c|c|}
\hline & \multicolumn{3}{|c|}{$\begin{array}{l}\text { Councilor runs } \\
\text { in any ward }\end{array}$} & \multicolumn{3}{|c|}{$\begin{array}{l}\text { Councilor runs } \\
\text { in other ward }\end{array}$} & \multicolumn{3}{|c|}{$\begin{array}{l}\text { Councilor runs } \\
\text { in other ward } \\
\text { controlled by party }\end{array}$} \\
\hline & (1) & (2) & (3) & (4) & (5) & (6) & (7) & (8) & (9) \\
\hline $\begin{array}{l}\text { T1: } 2012 \text { report }(\mathrm{ITT}) \times \text { Ineligible } \times \ldots \\
\quad \ldots \text { Pro-poor Spending Index }\end{array}$ & & & $\begin{array}{l}0.325^{* *} \\
(0.127)\end{array}$ & & & $\begin{array}{l}0.159^{* *} \\
(0.065)\end{array}$ & & & $\begin{array}{r}0.111^{*} \\
(0.059)\end{array}$ \\
\hline $\begin{array}{l}\text { T1: } 2012 \text { report }(\mathrm{ITT}) \times \text { Ineligible } \times \ldots \\
\quad \ldots \text { Attendance Index }\end{array}$ & & & $\begin{array}{l}1.615^{* *} \\
(0.807)\end{array}$ & & & $\begin{array}{c}1.106 \\
(0.679)\end{array}$ & & & $\begin{array}{l}1.087^{*} \\
(0.629)\end{array}$ \\
\hline $\begin{array}{l}\text { T2: } 2010 / 12 \text { reports }(\mathrm{ITT}) \times \text { Ineligible } \times \ldots \\
\quad \ldots \text { Pro-poor Spending Index }\end{array}$ & & & $\begin{array}{c}0.172 \\
(0.138)\end{array}$ & & & $\begin{array}{c}0.108 \\
(0.073)\end{array}$ & & & $\begin{array}{c}0.049 \\
(0.066)\end{array}$ \\
\hline $\begin{array}{l}\text { T2: } 2010 / 12 \text { reports }(\mathrm{ITT}) \times \text { Ineligible } \times \ldots \\
\ldots \text { Attendance Index }\end{array}$ & & & $\begin{array}{c}0.458 \\
(0.659)\end{array}$ & & & $\begin{array}{l}-0.406 \\
(0.332)\end{array}$ & & & $\begin{array}{l}-0.336 \\
(0.292)\end{array}$ \\
\hline $\begin{array}{l}\text { T1: } 2012 \text { report }(\text { ITT }) \times \ldots \\
\quad \ldots \text { Pro-poor Spending Index }\end{array}$ & & & $\begin{array}{l}-0.104 \\
(0.106)\end{array}$ & & & $\begin{array}{l}-0.040 \\
(0.033)\end{array}$ & & & $\begin{array}{c}0.002 \\
(0.017)\end{array}$ \\
\hline $\begin{array}{l}\text { T1: } 2012 \text { report }(\text { ITT }) \times \ldots \\
\quad \ldots \text { Attendance Index }\end{array}$ & & & $\begin{array}{l}-0.315 \\
(0.560)\end{array}$ & & & $\begin{array}{l}-0.124 \\
(0.117)\end{array}$ & & & $\begin{array}{l}-0.059 \\
(0.087)\end{array}$ \\
\hline $\begin{array}{l}\text { T2: } 2010 / 12 \text { reports }(\mathrm{ITT}) \times \ldots \\
\ldots \text { Pro-poor Spending Index }\end{array}$ & & & $\begin{array}{l}-0.059 \\
(0.101)\end{array}$ & & & $\begin{array}{l}-0.050 \\
(0.033)\end{array}$ & & & $\begin{array}{l}-0.007 \\
(0.017)\end{array}$ \\
\hline $\begin{array}{l}\text { T2: } 2010 / 12 \text { reports }(\text { ITT }) \times \ldots \\
\ldots \text { Attendance Index }\end{array}$ & & & $\begin{array}{l}-0.097 \\
(0.481)\end{array}$ & & & $\begin{array}{l}-0.052 \\
(0.133)\end{array}$ & & & $\begin{array}{l}-0.004 \\
(0.100)\end{array}$ \\
\hline T1: 2012 report $($ ITT $) \times$ Ineligible & & $\begin{array}{c}0.186 \\
(0.151)\end{array}$ & $\begin{array}{l}-0.876 \\
(0.564)\end{array}$ & & $\begin{array}{r}0.144^{*} \\
(0.086)\end{array}$ & $\begin{array}{l}-0.617 \\
(0.447)\end{array}$ & & $\begin{array}{c}0.097 \\
(0.073)\end{array}$ & $\begin{array}{c}-0.657^{*} \\
(0.392)\end{array}$ \\
\hline T2: 2010/12 reports $(\mathrm{ITT}) \times$ Ineligible & & $\begin{array}{c}0.043 \\
(0.128)\end{array}$ & $\begin{array}{c}-0.255 \\
(0.476)\end{array}$ & & $\begin{array}{c}0.166^{* *} \\
(0.070)\end{array}$ & $\begin{array}{c}0.423 \\
(0.258)\end{array}$ & & $\begin{array}{c}0.129^{* *} \\
(0.064)\end{array}$ & $\begin{array}{c}0.345 \\
(0.229)\end{array}$ \\
\hline T1: 2012 report (ITT) & $\begin{array}{c}0.076 \\
(0.083)\end{array}$ & $\begin{array}{c}0.013 \\
(0.112)\end{array}$ & $\begin{array}{c}0.217 \\
(0.395)\end{array}$ & $\begin{array}{c}0.035 \\
(0.032)\end{array}$ & $\begin{array}{l}-0.017 \\
(0.019)\end{array}$ & $\begin{array}{c}0.062 \\
(0.079)\end{array}$ & $\begin{array}{c}0.039 \\
(0.027)\end{array}$ & $\begin{array}{c}0.003 \\
(0.013)\end{array}$ & $\begin{array}{c}0.039 \\
(0.063)\end{array}$ \\
\hline T2: 2010/12 reports (ITT) & $\begin{array}{c}0.143^{*} \\
(0.074)\end{array}$ & $\begin{array}{c}0.096 \\
(0.091)\end{array}$ & $\begin{array}{c}0.162 \\
(0.335)\end{array}$ & $\begin{array}{c}0.041 \\
(0.025)\end{array}$ & $\begin{array}{c}-0.009 \\
(0.021)\end{array}$ & $\begin{array}{c}0.023 \\
(0.093)\end{array}$ & $\begin{array}{c}0.047^{* *} \\
(0.021)\end{array}$ & $\begin{array}{c}0.009 \\
(0.016)\end{array}$ & $\begin{array}{c}0.009 \\
(0.075)\end{array}$ \\
\hline Nontreatment Interactions & No & Yes & Yes & No & Yes & Yes & No & Yes & Yes \\
\hline Strata (zone-party) FE & Yes & Yes & Yes & Yes & Yes & Yes & Yes & Yes & Yes \\
\hline Ineligible control mean & 0.000 & 0.000 & 0.000 & 0.000 & 0.000 & 0.000 & 0.000 & 0.000 & 0.000 \\
\hline Eligible control mean & 0.478 & 0.478 & 0.478 & 0.022 & 0.022 & 0.022 & 0.000 & 0.000 & 0.000 \\
\hline Observations & 240 & 240 & 240 & 240 & 240 & 240 & 240 & 240 & 240 \\
\hline
\end{tabular}

Heteroskedasticity-robust standard errors in parentheses. $* p<.10, * * p<.05, * * * p<.01$.

Councilor-level cross section estimated with OLS. "Attendance Index" is overall councilor attendance at MCD committees of which they are a member, 2007-10. "Pro-poor Spending Index" is the mean z-score of three log preference-weighted spending amounts (2007-11), analogous to the dependent variable in Table I, column 3, for the pre-publication period. 
Table A.XI: Effect of newspaper report card publication, attendance, and spending on ward-level electoral outcomes

\begin{tabular}{|c|c|c|c|c|c|c|}
\hline & \multicolumn{3}{|c|}{ Voter turnout } & \multicolumn{3}{|c|}{ Voter registration } \\
\hline & (1) & (2) & (3) & (4) & (5) & (6) \\
\hline $\begin{array}{l}\text { Treatment } \times \text { Ineligible } \times \ldots \\
\quad \ldots \text { Pro-poor Spending Index }\end{array}$ & & & $\begin{array}{l}-0.003 \\
(0.017)\end{array}$ & & & $\begin{array}{l}-1464.691 \\
(3481.315)\end{array}$ \\
\hline $\begin{array}{l}\text { Treatment } \times \text { Ineligible } \times \ldots \\
\quad \ldots \text { Attendance Index }\end{array}$ & & & $\begin{array}{c}-0.135 \\
(0.093)\end{array}$ & & & $\begin{array}{c}5555.580 \\
(20582.760)\end{array}$ \\
\hline $\begin{array}{l}\text { Treatment } \times \ldots \\
\quad \ldots \text { Pro-poor Spending Index }\end{array}$ & & & $\begin{array}{c}-0.009 \\
(0.013)\end{array}$ & & & $\begin{array}{c}1765.208 \\
(2774.616)\end{array}$ \\
\hline $\begin{array}{l}\text { Treatment } \times \ldots \\
\quad \ldots \text { Attendance Index }\end{array}$ & & & $\begin{array}{c}0.097^{*} \\
(0.054)\end{array}$ & & & $\begin{array}{c}-5912.027 \\
(16480.880)\end{array}$ \\
\hline Treatment $\times$ Ineligible & & $\begin{array}{l}-0.001 \\
(0.015)\end{array}$ & $\begin{array}{c}0.089 \\
(0.063)\end{array}$ & & $\begin{array}{c}-460.830 \\
(2519.533)\end{array}$ & $\begin{array}{c}-4065.476 \\
(14371.841)\end{array}$ \\
\hline Treatment & $\begin{array}{l}-0.008 \\
(0.007)\end{array}$ & $\begin{array}{l}-0.008 \\
(0.009)\end{array}$ & $\begin{array}{l}-0.074^{* *} \\
(0.035)\end{array}$ & $\begin{array}{c}-744.579 \\
(1420.318)\end{array}$ & $\begin{array}{c}-702.669 \\
(1941.576)\end{array}$ & $\begin{array}{c}3343.741 \\
(11956.598)\end{array}$ \\
\hline Nontreatment Interactions & No & Yes & Yes & No & Yes & Yes \\
\hline Strata (zone-party) FE & Yes & Yes & Yes & Yes & Yes & Yes \\
\hline Ineligible control mean & 0.534 & 0.534 & 0.534 & 40226.269 & 40226.269 & 40226.269 \\
\hline Eligible control mean & 0.554 & 0.554 & 0.554 & 43269.239 & 43269.239 & 43269.239 \\
\hline Observations & 240 & 240 & 240 & 240 & 240 & 240 \\
\hline
\end{tabular}

Heteroskedasticity-robust standard errors in parentheses. ${ }^{*} p<.10,{ }^{* *} p<.05,{ }^{* * *} p<.01$.

Ward-level cross section estimated with OLS. "Attendance Index" is overall councilor attendance at MCD committees of which they are a member, 2007-10. "Pro-poor Spending Index" is the mean z-score of three log preference-weighted spending amounts (2007-11), analogous to the dependent variable in Table I, column 3, for the pre-publication period. 